\title{
Advanced Research on the Antioxidant Activity and Mechanism of Polyphenols from Hippophae Species-A Review
}

\author{
Mingyue Ji ${ }^{1}$, Xue Gong ${ }^{1}$, Xue $\mathrm{Li}^{2}$, Congcong Wang ${ }^{1}$ and Minhui $\mathrm{Li}^{1,2,3,4,5, * \mathbb{C}}$ \\ 1 Department of Pharmacy, Baotou Medical College, Baotou 014060, China; Jimingyue9@163.com (M.J.); \\ gongxue_2017@yeah.net (X.G.); Wangcongcong0@163.com (C.W.) \\ 2 Department of Pharmacy, Inner Mongolia Medical University, Hohhot 010110, China; lixue950119@163.com \\ 3 Qiqihar Medical University, Qiqihar 161006, China \\ 4 Pharmaceutical Laboratory, Inner Mongolia Autonomous Region Academy of Chinese Medicine, \\ Hohhot 010020, China \\ 5 Inner Mongolia Key Laboratory of Characteristic Geoherbs Resources Protection and Utilization, \\ Baotou Medical College, Baotou 014060, China \\ * Correspondence: prof_liminhui@yeah.net; Tel.: +86-472-716-7795
}

Academic Editors: Paola Di Donato and Brigida Silvestri

Received: 4 February 2020; Accepted: 18 February 2020; Published: 19 February 2020

\begin{abstract}
Oxidation is a normal consequence of metabolism in biological organisms. The result is the formation of detrimental reactive oxygen species (ROS) and reactive nitrogen species (RNS). A large number of studies have shown that polyphenolic compounds have good antioxidant properties. Hippophae species plants have high polyphenolic content and are widely used in food, medicinal, or the cosmetic field. The main polyphenols in Hippophae species are flavonoids, phenolic acids and tannins, which have multiple effects. However, there is a limited number of studies on polyphenols in Hippophae species plants. This review systematically summarizes the polyphenols compounds and antioxidant activity of Hippophae species plants, and it is noteworthy that the main mechanisms of the polyphenols of Hippophae with antioxidant activity have been summarized as follows: regulating enzyme activity, affect the antioxidant reaction of cells, and others. This review provides useful information for the further study and application of Hippophae species polyphenols and their antioxidant activity.
\end{abstract}

Keywords: Hippophae species; polyphenols; antioxidant activity; applications

\section{Introduction}

Oxidation is a natural consequence of metabolism in biological organisms. The result is the formation of detrimental reactive oxygen species (ROS) and reactive nitrogen species (RNS), such as superoxide, hydrogen peroxide, singlet oxygen and nitric oxide radicals. Normally, the antioxidant system in the human body can scavenge these radicals, thereby maintaining the balance between oxidation and antioxidation. However, when the body cannot eliminate excessive ROS using the intracellular antioxidant enzyme system and extracellular antioxidant compounds, oxidative stress will occur, leading to chronic and degenerative diseases, such as osteoarthritis, atherosclerosis, cancer and other degenerative diseases related to aging [1-3].

Hippophae is a member of the Elaeagnaceae family, in which 7 species and 11 subspecies have been identified worldwide [4]. Hippophae is widely used in various fields, such as the food, medicine and cosmetic industries. Hippophae rhamnoides L., the representative plant of the genus Hippophae, can be used as a food and medicine [5] (Figure 1). Studies have shown that various nutrients and bioactive components are present in Hippophae. These include minerals, vitamins, polysaccharides, unsaturated fatty acid, terpenoids, polyphenolic compounds, nonsteroidal compounds, flavonoids, organic acids 
and volatile components, which have antioxidant, anti-inflammatory, anti-radiation and curative effects on burns and ulcers [6,7]. Polyphenols are secondary plant metabolites, arising from phenylalanine or shikimic acid, playing a pivotal role in counteracting various type of stress, other than contributing to the organoleptic properties of plants and plant-derived food [8]. In addition, it is well known that polyphenols exert beneficial effects upon human health, due to their antioxidant, anti-inflammatory, cardioprotective, anticancer and antimicrobial properties $[9,10]$. The antioxidant activity of sea buckthorn (H. rhamnoides L.) is mainly due to the redox characteristics of polyphenolic compounds, which mainly contain flavonoids, phenolic acids and tannins. In particular, kaempferol, quercetin, isorhamnetin, catechin, procyanidins and gallic acid are commonly present as bioactive compounds [11]. H. rhamnoides L. is a good source of active phenols for human consumption, and it plays an important role in many physiological and metabolic processes. The active compounds and metabolites of Hippophae plants have an antioxidant effect, making them suitable candidates of new functional foods [12]. In addition, Hippophae is rich in unsaturated fatty acids; its unsaturated fatty acid content is higher than its saturated fatty acid content, which usually accounts for approximately $58 \%$ to $88.9 \%$ of the total fatty acids. The content of the seed of Hippophae is the highest, which leads to the rich biological activity of sea-buckthorn oil. Hippophae plants are also rich in carotenoids, which have anticancer, anti-ulcer and growth-stimulating effects. Therefore, sea buckthorn is a promising plant containing many dietary and medicinal compounds with potential beneficial applications for improving human health [13].

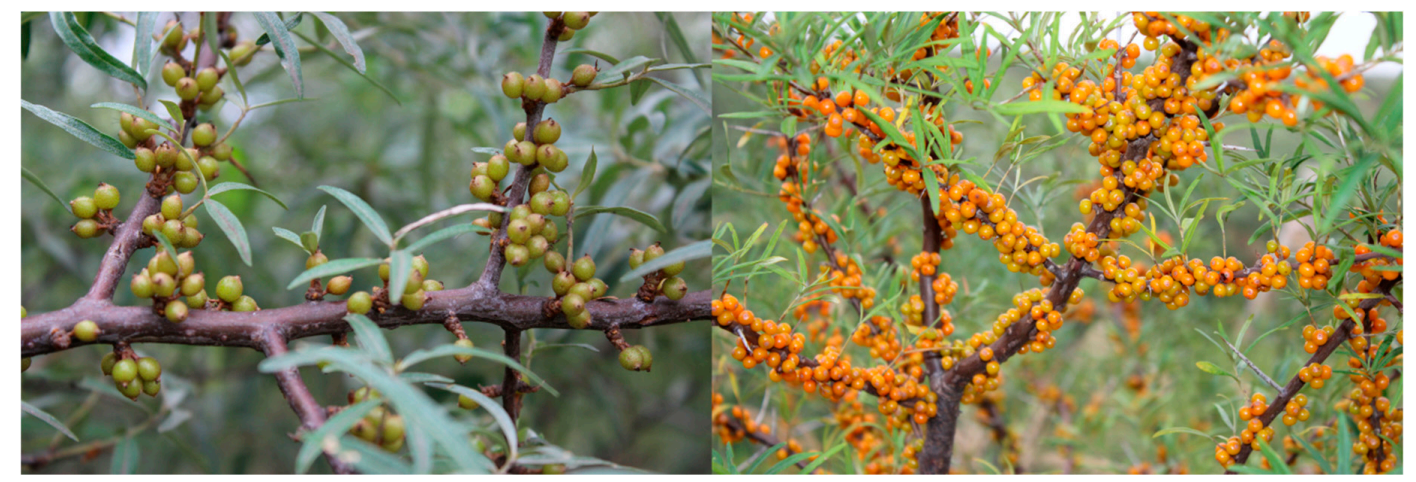

Figure 1. The fruit of sea buckthorn (H. rhamnoides L.).

After a thorough literature search, we found that there is no comprehensive literature review on the antioxidant activity and mechanism of polyphenol compounds of Hippophae species. In this review, we present a comprehensive overview and the latest information on the chemical constituents, antioxidant activity and application of polyphenols from Hippophae species. We also provide a theoretical basis for the further development and utilization of Hippophae species.

\section{Chemical Constituents and Structures of Polyphenols}

Polyphenols in Hippophae species are mainly flavonoids and phenolic acids, and research has shown that polyphenol content in the fruit of H. rhamnoides L. subsp. wolongensis ranges from 29.8 to $38.8 \mathrm{mg}$ GAE/g (GAE, gallic acid equivalents) [14], higher than that in mulberry (4.44 mg GAE/g) [15], pomegranate (3.90 mg GAE/g), red raspberries (3.00 mg GAE/g), blueberry $(8.40 \mathrm{mg} \mathrm{GAE} / \mathrm{g}$ ) and blackberry $(7.40 \mathrm{mg} \mathrm{GAE} / \mathrm{g})$ [16]. In addition, it has been reported that the total polyphenol content of sea buckhorn leaf (H. rhamnoides L., Korea) and green tea extracts (young tea leaves harvested in Jeju Island, Korea) ranged from 23.0 to $66.0 \mathrm{mg} \mathrm{GAE} / \mathrm{g}$ and from 33.0 to $118.0 \mathrm{mg} \mathrm{GAE} / \mathrm{g}$, respectively [17]. However, compared with those of green tea from other regions $(37.4 \mathrm{mg} \mathrm{GAE} / \mathrm{g}$; fresh tea leaves harvested in Guizhou Province, China), the polyphenol content of sea buckthorn also has some advantages [18]. Although the polyphenol contents in berries and leaves vary depending on the species, geographical location and the degree of physiological maturity, they are the most important active ingredients 
contributing to the antioxidant activities of Hippophae species. Nearly 100 polyphenolic compounds have been isolated and identified from the Hippophae species, as shown in Figure 2.

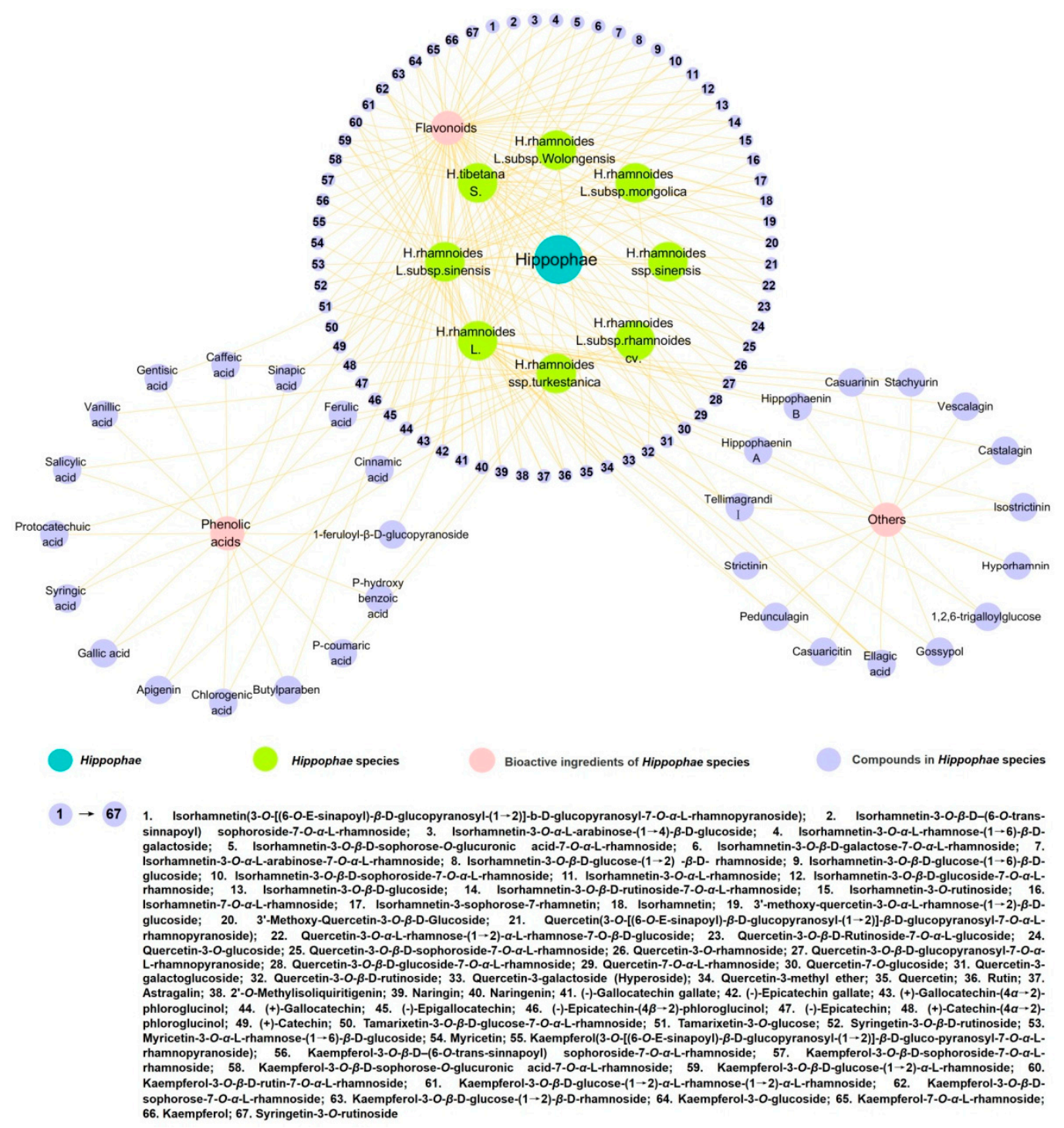

Figure 2. Polyphenolic compounds from the Hippophae species.

\subsection{Flavonoids}

Flavonoids are natural polyphenol compounds widely distributed in Hippophae species. They are mostly found in the fruits and leaves of the plant. According to their parent nuclear, flavonoids are divided into flavonoids, flavanols and flavanones in Hippophae species. Isorhamnetin, quercetin and kaempferol [19] are the main flavonoids found in Hippophae species.

The flavonoids (vitamin P) of Hippophae species are often used as inhibitors of ascorbic acid oxidation, especially in treating cardiovascular diseases [20]. Xing [21] found that the total flavonoids in the leaves, pulp, pericarp and seeds of Hippophae species were $2.24 \%, 0.95 \%, 0.51 \%$ and $0.31 \%$, respectively, indicating that the leaves have the highest total flavonoid content. Fu [22] used spectrophotometry to measure and compare the total flavonoid content in the leaves of different Hippophae species; the results showed that the total flavonoid content in H. rhamnoides L. subsp. sinensis and $H$. gyantsensis were the highest $(0.7392 \%$ and $0.7814 \%$, respectively), followed by that in $H$. tibetana S. and $H$. rhamnoides L. subsp. yunnanensis $(0.5879 \%$ and $0.4980 \%$, respectively). The chemical constituents and structures of flavonoids in Hippophae species are shown in Figure 3 and Table 1. 
<smiles>[R20]Oc1cc(O)c2c(=O)c(O[R2])c(-c3cc([R])c([R])c([R])c3)oc2c1</smiles>

A<smiles>[R]c1cc(O)c2c(c1)OC(c1ccc(O)cc1)CC2=O</smiles>

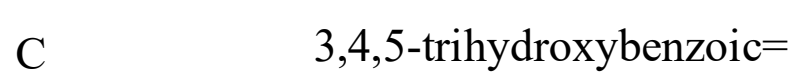<smiles>O=c1cc(-c2ccc(O)cc2)oc2cc(O)cc(O)c12</smiles>
68<smiles>[R]c1cc(C2Oc3cc(O)cc(O)c3C([R])([R])C2([R])[R])cc([R])c1O</smiles>

B<smiles>Cc1c(O)cc(O)cc1O</smiles><smiles>COC(=O)c1cc(O)c(O)c(O)c1</smiles><smiles>COc1cc(O)ccc1C(=O)/C=C/c1ccc(O)cc1</smiles>

Figure 3. Chemical structures of flavonoids from Hippophae species. 
Table 1. Flavonoids from Hippophae species.

\begin{tabular}{|c|c|c|c|c|c|c|c|c|c|c|}
\hline No. & Compounds & Skeletons & $\mathbf{R}^{1}$ & $\mathbf{R}^{2}$ & $\mathbf{R}^{3}$ & $\mathbf{R}^{4}$ & $\mathbf{R}^{5}$ & $\mathrm{R}^{6}$ & Species & Ref. \\
\hline 1 & Astragalin & A & Glu & $\mathrm{H}$ & $\mathrm{H}$ & $\mathrm{OH}$ & $\mathrm{H}$ & - & H. rhamnoides $\mathrm{L}$. & [23] \\
\hline 2 & Rutin & A & Rut & $\mathrm{H}$ & $\mathrm{H}$ & $\mathrm{OH}$ & $\mathrm{OH}$ & - & $\begin{array}{l}\text { H. rhamnoides } \mathrm{L} \text {. subsp. } \\
\text { sinensis, } \\
\text { H. tibetana } \mathrm{S} ., \\
\text { H. rhamnoides } \mathrm{L} \text {. } \\
\end{array}$ & {$[24,25]$} \\
\hline 3 & Quercetin & A & $\mathrm{H}$ & $\mathrm{H}$ & $\mathrm{H}$ & $\mathrm{OH}$ & $\mathrm{OH}$ & - & $\begin{array}{l}\text { H. rhamnoides L. subsp. } \\
\text { Wolongensis }\end{array}$ & [14] \\
\hline 4 & Quercetin-3-methyl ether & A & Me & $\mathrm{H}$ & $\mathrm{H}$ & $\mathrm{OH}$ & $\mathrm{H}$ & - & H. rhamnoides $\mathrm{L}$. & [26] \\
\hline 5 & Quercetin-3-galactoside (Hyperoside) & A & Gal & $\mathrm{H}$ & $\mathrm{H}$ & $\mathrm{OH}$ & $\mathrm{OH}$ & - & H. rhamnoides $\mathrm{L}$. & [27] \\
\hline 6 & Quercetin-3-O- $\beta$-D-rutinoside & A & Rut & $\mathrm{H}$ & $\mathrm{H}$ & $\mathrm{OH}$ & $\mathrm{OH}$ & - & $\begin{array}{l}\text { H. rhamnoides L. subsp. } \\
\text { mongolica }\end{array}$ & {$[28,29]$} \\
\hline 7 & Quercetin-3-galactoglucoside & A & Gal & $\mathrm{H}$ & - & $\mathrm{H}$ & $\mathrm{OH}$ & - & $\begin{array}{l}\text { H. rhamnoides L. subsp. } \\
\text { sinensis }\end{array}$ & [28] \\
\hline 8 & Quercetin-7-O-glucoside & A & $\mathrm{H}$ & Glu & $\mathrm{H}$ & $\mathrm{OH}$ & $\mathrm{OH}$ & - & $\begin{array}{l}\text { H. rhamnoides } \mathrm{L} \text {. subsp. } \\
\text { sinensis, } \\
\text { H. tibetana S. } \\
\end{array}$ & {$[25,26,30]$} \\
\hline 9 & Quercetin-7-O- $\alpha$-L-rhamnoside & A & $\mathrm{H}$ & Rha & $\mathrm{H}$ & $\mathrm{OH}$ & $\mathrm{OH}$ & - & $\begin{array}{l}\text { H. rhamnoides } \mathrm{L} \text {. subsp. } \\
\text { sinensis, } \\
\text { H. tibetana } \mathrm{S} \text {. }\end{array}$ & [25] \\
\hline 10 & Quercetin-3-O- $\beta$-D-glucoside-7-O- $\alpha$-L-rhamnoside & A & Glu & Rha & $\mathrm{H}$ & $\mathrm{OH}$ & $\mathrm{OH}$ & - & $\begin{array}{l}\text { H. rhamnoides L. subsp. } \\
\text { sinensis }\end{array}$ & [31] \\
\hline 11 & $\begin{array}{l}\text { Quercetin-3-O- } \beta \text {-D-glucopyranosyl-7-O- } \alpha \text { - } \\
\text { L-rhamnopyranoside }\end{array}$ & A & Glu & Rha & $\mathrm{H}$ & $\mathrm{OH}$ & $\mathrm{OH}$ & - & H. rhamnoides $\mathrm{L}$. & [23] \\
\hline 12 & Quercetin-3-O-rhamnoside & A & Rha & $\mathrm{H}$ & $\mathrm{H}$ & $\mathrm{OH}$ & $\mathrm{OH}$ & - & $\begin{array}{l}\text { H. rhamnoides L. subsp. } \\
\text { sinensis, } \\
\text { H. tibetana } \mathrm{S} . \\
\end{array}$ & [32] \\
\hline 13 & Quercetin-3-O- $\beta-\mathrm{D}$-sophoroside-7-O- $\alpha$-L-rhamnoside & A & Sop & Rha & $\mathrm{H}$ & $\mathrm{OH}$ & $\mathrm{OH}$ & - & $\begin{array}{l}\text { H. rhamnoides L. subsp. } \\
\text { sinensis, } \\
\text { H. tibetana } \mathrm{S} \text {. }\end{array}$ & [25] \\
\hline 14 & Quercetin-3-O-glucoside & A & Glu & $\mathrm{H}$ & $\mathrm{H}$ & $\mathrm{OH}$ & $\mathrm{OH}$ & - & $\begin{array}{l}\text { H. rhamnoides L. subsp. } \\
\text { sinensis }\end{array}$ & [29] \\
\hline 15 & Quercetin-3-O- $\beta$-D- Rutinoside-7-O- $\alpha$-L-glucoside & A & Rut & Glu & $\mathrm{H}$ & $\mathrm{OH}$ & $\mathrm{OH}$ & - & H. tibetana S. & [25] \\
\hline 16 & Quercetin-3-methyl ether & A & $\mathrm{OCH} 3$ & $\mathrm{H}$ & $\mathrm{H}$ & $\mathrm{OH}$ & $\mathrm{H}$ & - & H. rhamoides $\mathrm{L}$. & [26] \\
\hline 17 & $\begin{array}{l}\text { Quercetin-3-O- } \alpha \text {-L-rhamnose-( }(1 \rightarrow 2)-\alpha \text {-L-rhamnose- } \\
\text { 7-O- } \beta \text {-D-glucoside }\end{array}$ & A & Rha-Rha & Glu & $\mathrm{OH}$ & $\mathrm{OH}$ & $\mathrm{H}$ & - & $\begin{array}{l}\text { H. rhamnoides } \mathrm{L} \text {. subsp. } \\
\text { sinensis, } \\
\text { H. tibetana } \mathrm{S} \text {. }\end{array}$ & [25] \\
\hline 18 & $\begin{array}{l}\text { Quercetin(3-O-[(6-O-E-sinapoyl)- } \beta \text {-D-glucopyranosyl- } \\
(1 \rightarrow 2)]-\beta \text {-D-glucopyranosyl-7-O- } \alpha \text {-L-rhamnopyranoside) }\end{array}$ & A & Glc-(2"'-O-Glc)-(6"'-O-E-sinapoyl) & Glu & $\mathrm{OH}$ & $\mathrm{OH}$ & $\mathrm{H}$ & - & H. rhamnoides ssp. sinensis & [33] \\
\hline 19 & 3'-Methoxy-Quercetin-3-O- $\beta$-D-Glucoside & A & Glu & $\mathrm{H}$ & $\mathrm{OMe}$ & $\mathrm{OH}$ & $\mathrm{H}$ & - & H. tibetana S. & [34] \\
\hline 20 & 3'-methoxy-quercetin-3-O- $\alpha$ - - -rhamnose- $(1 \rightarrow 2)-\beta$-D-glucoside & A & Rha-Glu & $\mathrm{H}$ & $\mathrm{OMe}$ & $\mathrm{OH}$ & $\mathrm{H}$ & - & H. tibetana S. & [34] \\
\hline
\end{tabular}


Table 1. Cont.

\begin{tabular}{|c|c|c|c|c|c|c|c|c|c|c|}
\hline No. & Compounds & Skeletons & $\mathbf{R}^{1}$ & $\mathbf{R}^{2}$ & $\mathbf{R}^{3}$ & $\mathbf{R}^{4}$ & $\mathbf{R}^{5}$ & $\mathbf{R}^{6}$ & Species & Ref. \\
\hline 21 & Isorhamnetin & A & $\mathrm{H}$ & $\mathrm{H}$ & OMe & $\mathrm{OH}$ & $\mathrm{H}$ & - & $\begin{array}{l}\text { H. rhamnoides L. subsp. } \\
\text { Wolongensis, } \\
\text { H. rhamnoides L. subsp. } \\
\text { sinensis, } \\
\text { H. tibetana S. }\end{array}$ & {$[14,25]$} \\
\hline 22 & Isorhamnetin-3-sophorose-7-rhamnetin & A & Sop & Glu & $\mathrm{H}$ & $\mathrm{H}$ & OMe & - & $\begin{array}{l}\text { H. rhamnoides L. subsp. } \\
\text { sinensis }\end{array}$ & [28] \\
\hline 23 & Isorhamnetin-7-O- $\alpha$-L-rhamnoside & A & $\mathrm{H}$ & Rha & $\mathrm{H}$ & $\mathrm{OH}$ & $\mathrm{OMe}$ & - & H. rhamnoides $\mathrm{L}$. & [26] \\
\hline 24 & Isorhamnetin-3-O-rutinoside & A & Rut & $\mathrm{H}$ & $\mathrm{H}$ & $\mathrm{OH}$ & OMe & - & $\begin{array}{l}\text { H. rhamnoides L. subsp. } \\
\text { sinensis, } \\
\text { H. tibetana } \mathrm{S} \text {. }\end{array}$ & {$[25,29,32]$} \\
\hline 25 & Isorhamnetin-3-O- $\beta$-D-rutinoside-7-O- $\alpha$-L-rhamnoside & A & Rut & Rha & $\mathrm{H}$ & OMe & $\mathrm{OH}$ & - & $\begin{array}{l}\text { H. rhamnoides } \mathrm{L} \text {. subsp. } \\
\text { sinensis, } \\
\text { H. tibetana } \mathrm{S} \text {. }\end{array}$ & [25] \\
\hline 26 & Isorhamnetin-3-O- $\beta$-D-glucoside & A & Glu & $\mathrm{H}$ & $\mathrm{H}$ & $\mathrm{OMe}$ & $\mathrm{H}$ & - & $\begin{array}{l}\text { H. rhamnoides L. subsp. } \\
\text { sinensis, } \\
\text { H. tibetana S. }\end{array}$ & [25] \\
\hline 27 & Isorhamnetin-3-O- $\beta-\mathrm{D}$-glucoside-7-O- $\alpha$-L-rhamnoside & A & Glu & Rha & $\mathrm{H}$ & $\mathrm{OH}$ & OMe & - & $\begin{array}{l}\text { H. rhamnoides } \mathrm{L} \text {. subsp. } \\
\text { sinensis, } \\
\text { H. tibetana } \mathrm{S} \text {. }\end{array}$ & [25] \\
\hline 28 & Isorhamnetin-3-O- $\alpha$-L-rhamnoside & A & Rha & $\mathrm{H}$ & $\mathrm{H}$ & $\mathrm{OH}$ & OMe & - & H. rhamnoides L. & [26] \\
\hline 29 & Isorhamnetin-3-O- $\beta$-D-sophoroside-7-O- $\alpha$-L-rhamnoside & A & Sop & Rha & $\mathrm{H}$ & $\mathrm{OH}$ & OMe & - & $\begin{array}{l}\text { H. rhamnoides L. subsp. } \\
\text { sinensis, } \\
\text { H. tibetana } \mathrm{S} \text {. }\end{array}$ & [29] \\
\hline 30 & Isorhamnetin-3-O- $\beta$-D-glucose- $(1 \rightarrow 6)-\beta$-D-glucoside & A & Glu-Glu & $\mathrm{OH}$ & $\mathrm{OMe}$ & $\mathrm{OH}$ & $\mathrm{H}$ & - & H. rhamnoides $\mathrm{L}$. & [26] \\
\hline 31 & Isorhamnetin-3-O- $\beta$-D-glucose- $(1 \rightarrow 2)-\beta-\mathrm{D}$ - rhamnoside & A & Glu-Glu & Rha & OMe & $\mathrm{OH}$ & $\mathrm{H}$ & - & $\begin{array}{l}\text { H. rhamnoides L. subsp. } \\
\text { sinensis }\end{array}$ & [29] \\
\hline 32 & Isorhamnetin-3-O- $\alpha$-L-arabinose-7-O- $\alpha$-L-rhamnoside & A & Ara & Rha & OMe & $\mathrm{OH}$ & $\mathrm{H}$ & - & $\begin{array}{l}\text { H. rhamnoides L. subsp. } \\
\text { sinensis, } \\
\text { H. rhamnoides }\end{array}$ & [25] \\
\hline 33 & Isorhamnetin-3-O- $\beta$-D-galactose-7-O- $\alpha$-L-rhamnoside & A & Gal & Rha & OMe & $\mathrm{OH}$ & $\mathrm{H}$ & - & $\begin{array}{l}\text { H. rhamnoides } \mathrm{L} \text {. subsp. } \\
\text { sinensis, } \\
\text { H. rhamnoides } \mathrm{L} \text {. }\end{array}$ & [35] \\
\hline 34 & $\begin{array}{l}\text { Isorhamnetin-3-O- } \beta \text {-D-Dophorose-O-glucuronic } \\
\text { acid-7-O- } \alpha \text {-L-rhamnoside }\end{array}$ & A & Sop-O-GA & Rha & OMe & $\mathrm{OH}$ & $\mathrm{H}$ & - & $\begin{array}{l}\text { H. tibetana S., } \\
\text { H. rhamnoides L. }\end{array}$ & [25] \\
\hline 35 & Isorhamnetin-3-O- $\alpha$-L-rhamnose-( $(1 \rightarrow 6)-\beta$-D-galactoside & A & Rha-Gal & $\mathrm{H}$ & OMe & $\mathrm{OH}$ & $\mathrm{H}$ & - & H. rhamnoides $\mathrm{L}$. & [26] \\
\hline 36 & Isorhamnetin-3-O- $\alpha$-L-arabinose-( $(1 \rightarrow 4)$ - $\beta$-D-glucoside & A & Ara-Glu & $\mathrm{H}$ & $\mathrm{OMe}$ & $\mathrm{OH}$ & $\mathrm{H}$ & - & H. rhamnoides $\mathrm{L}$. & [26] \\
\hline 37 & $\begin{array}{l}\text { Isorhamnetin-3-O- } \beta \text {-D-(6-O-trans-sinnapoyl) } \\
\text { sophoroside-7-O- } \alpha \text {-L-rramnoside }\end{array}$ & A & (6-O-trans-sinnapoyl) Sop & Rha & OMe & $\mathrm{OH}$ & $\mathrm{H}$ & - & $\begin{array}{l}\text { H. rhamnoides L. subsp. } \\
\text { sinensis }\end{array}$ & [31] \\
\hline 38 & $\begin{array}{l}\text { Isorhamnetin(3-O-[(6-O-E-sinapoyl)- } \beta \text {-D-glucopyranosyl- } \\
(1 \rightarrow 2)]- \text {-D-D-glucopyranosyl-7-O-a-L-rhamnopyranoside) }\end{array}$ & A & Glc-(2"'-O-Glc)-(6"'"-O-E-sinapoyl) & Glu & OMe & $\mathrm{OH}$ & $\mathrm{H}$ & - & H. rhamnoides ssp. sinensis & [33] \\
\hline
\end{tabular}


Table 1. Cont.

\begin{tabular}{|c|c|c|c|c|c|c|c|c|c|c|}
\hline No. & Compounds & Skeletons & $\mathrm{R}^{1}$ & $\mathbf{R}^{2}$ & $\mathbf{R}^{3}$ & $\mathbf{R}^{4}$ & $\mathbf{R}^{5}$ & $R^{6}$ & Species & Ref. \\
\hline 39 & syringetin-3-O-rutinoside & A & Rut & $\mathrm{H}$ & OMe & $\mathrm{OH}$ & OMe & - & $\begin{array}{l}\text { H. rhamnoides } \mathrm{L} \text {. subsp. } \\
\text { sinensis }\end{array}$ & [29] \\
\hline 40 & Kaempferol & A & $\mathrm{H}$ & $\mathrm{H}$ & $\mathrm{H}$ & $\mathrm{OH}$ & $\mathrm{H}$ & - & $\begin{array}{l}\text { H. rhamnoides L. subsp. } \\
\text { Wolongensis }\end{array}$ & [14] \\
\hline 41 & Kaempferol-7-O- $\alpha$-L-rhamnoside & A & $\mathrm{H}$ & Rha & $\mathrm{H}$ & $\mathrm{OH}$ & $\mathrm{H}$ & - & $\begin{array}{l}\text { H. rhamnoides L. subsp. } \\
\text { sinensis, } \\
\text { H. tibetana S. } \\
\end{array}$ & [29] \\
\hline 42 & Kaempferol-3-O-glucoside & A & Glu & $\mathrm{H}$ & $\mathrm{H}$ & $\mathrm{OH}$ & $\mathrm{H}$ & - & $\begin{array}{l}\text { H. rhamnoides } \mathrm{L} \text {. subsp. } \\
\text { sinensis, } \\
\text { H. tibetana } \mathrm{S} \text {. }\end{array}$ & [25] \\
\hline 43 & Kaempferol-3-O- $\beta$-D-glucose-(1 $\rightarrow 2)-\beta$-D-rhamnoside & A & Glu-Glu & Rha & OMe & $\mathrm{OH}$ & $\mathrm{H}$ & - & $\begin{array}{l}\text { H. rhamnoides L. subsp. } \\
\text { sinensis, }\end{array}$ & [29] \\
\hline 44 & Kaempferol-3-O- $\beta$-D-sophorose-7-O- $\alpha$-L-rhamnoside & A & Sop & Rha & $\mathrm{H}$ & $\mathrm{OH}$ & $\mathrm{H}$ & - & $\begin{array}{l}\text { H. rhamnoides } \mathrm{L} \text {. subsp. } \\
\text { sinensis, } \\
\text { H. tibetana } \mathrm{S} ., \\
\text { H. rhamnoides } \mathrm{L} .\end{array}$ & {$[25,28]$} \\
\hline 45 & $\begin{array}{l}\text { Kaempferol-3-O- } \beta \text {-D-glucose-(1 } \rightarrow 2) \text { - } \alpha \text {-L-rhamnose- } \\
(1 \rightarrow 2)-\alpha \text {-L-rhamnoside }\end{array}$ & A & Glu-Rha-Rha & $\mathrm{H}$ & $\mathrm{H}$ & $\mathrm{OH}$ & $\mathrm{H}$ & - & H. rhamnoides $\mathrm{L}$. & [26] \\
\hline 46 & Kaempferol-3-O- $\beta$-D-rutin-7-O- $\alpha$-L-rhamnoside & A & Rut & Rha & $\mathrm{H}$ & $\mathrm{OH}$ & $\mathrm{H}$ & - & $\begin{array}{l}\text { H. rhamnoides } \mathrm{L} \text {. subsp. } \\
\text { sinensis, } \\
\text { H. tibetana } \mathrm{S} ., \\
\text { H. rhamnoides } \mathrm{L} .\end{array}$ & {$[25,26]$} \\
\hline 47 & Kaempferol-3-O- $\beta$-D-glucose-( $(1 \rightarrow 2)$ - $\alpha$-L-rhamnoside & A & GluRha & $\mathrm{H}$ & $\mathrm{H}$ & $\mathrm{OH}$ & $\mathrm{H}$ & - & $\begin{array}{l}\text { H. rhamnoides } \mathrm{L} \text {. subsp. } \\
\text { sinensis, } \\
\text { H. tibetana } \mathrm{S} ., \\
\text { H. rhamnoides } \mathrm{L} .\end{array}$ & {$[25,26]$} \\
\hline 48 & $\begin{array}{l}\text { Kaempferol-3-O- } \beta \text {-D-sophorose-O-glucuronic } \\
\text { acid-7-O- } \alpha \text {-L-rhamnoside }\end{array}$ & A & Sop-O-GA & Rha & $\mathrm{H}$ & $\mathrm{OH}$ & $\mathrm{H}$ & - & $\begin{array}{l}\text { H. tibetana S., } \\
\text { H. rhamnoides L. }\end{array}$ & {$[25,26]$} \\
\hline 49 & Kaempferol-3-O- $\beta$-D-sophoroside-7-O- $\alpha$-L-rhamnoside & A & Sop & Rha & $\mathrm{H}$ & $\mathrm{OH}$ & $\mathrm{H}$ & - & $\begin{array}{l}\text { H. rhamnoides L. subsp. } \\
\text { sinensis }\end{array}$ & [29] \\
\hline 50 & $\begin{array}{l}\text { Kaempferol-3-O- } \beta \text {-D-(6-O-trans-sinnapoyl) } \\
\text { sophoroside-7-O- } \alpha \text {-L-rhamnoside }\end{array}$ & A & (6-O-trans-sinnapoyl) Sop & Rha & $\mathrm{H}$ & $\mathrm{OH}$ & $\mathrm{H}$ & - & $\begin{array}{l}\text { H. rhamnoides L. subsp. } \\
\text { sinensis }\end{array}$ & [31] \\
\hline 51 & $\begin{array}{l}\text { Kaempferol(3-O-[(6-O-E-sinapoyl)- } \beta \text {-D-glucopyranosyl- } \\
(1 \rightarrow 2)]-\beta \text {-D-gluco-pyranosyl-7-O-O-L-Dhamnopyranoside) }\end{array}$ & A & Glc-(2"'-O-Glc)-(6"'-O-E-sinapoyl) & Glu & $\mathrm{H}$ & $\mathrm{OH}$ & $\mathrm{H}$ & - & H. rhamnoides ssp. sinensis & [33] \\
\hline 52 & Myricetin & A & $\mathrm{H}$ & $\mathrm{H}$ & $\mathrm{OH}$ & $\mathrm{OH}$ & $\mathrm{OH}$ & - & H. rhamnoides $\mathrm{L}$. & [26] \\
\hline 53 & Myricetin-3-O- $\alpha$-L-rhamnose-( $(1 \rightarrow 6)-\beta-\mathrm{D}$-glucoside & A & $\mathrm{H}$ & $\mathrm{H}$ & $\mathrm{OH}$ & $\mathrm{OH}$ & $\mathrm{H}$ & - & $\begin{array}{l}\text { H. rhamnoides } \mathrm{L} \text {. subsp. } \\
\text { sinensis, } \\
\text { H. rhamnoides } \mathrm{L} \text {. }\end{array}$ & {$[25,26]$} \\
\hline 54 & Syringetin-3-O- $\beta$-D-rutinoside & A & Rut & $\mathrm{H}$ & OMe & $\mathrm{OH}$ & OMe & - & $\begin{array}{l}\text { H. rhamnoides L. subsp. } \\
\text { sinensis, }\end{array}$ & [29] \\
\hline
\end{tabular}


Table 1. Cont

\begin{tabular}{|c|c|c|c|c|c|c|c|c|c|c|}
\hline No. & Compounds & Skeletons & $\mathrm{R}^{1}$ & $\mathbf{R}^{2}$ & $\mathbf{R}^{3}$ & $\mathrm{R}^{4}$ & $\mathbf{R}^{5}$ & $\mathrm{R}^{6}$ & Species & Ref. \\
\hline 55 & Tamarixetin-3-O-glucose & A & Glu & $\mathrm{H}$ & $\mathrm{OH}$ & $\mathrm{OH}$ & $\mathrm{H}$ & - & $\begin{array}{l}\text { H. rhamnoides L. subsp. } \\
\text { mongolica, } \\
\text { H. rhamnoides L. }\end{array}$ & {$[26,28]$} \\
\hline 56 & Tamarixetin-3-O- $\beta$-D-glucose-7-O- $\alpha$-L-rhamnoside & A & Glu & Rha & $\mathrm{OH}$ & $\mathrm{OH}$ & $\mathrm{H}$ & - & $\begin{array}{l}\text { H. rhamnoides L. subsp. } \\
\text { mongolica }\end{array}$ & [28] \\
\hline 57 & (+)-Catechin & B & $\mathrm{H}$ & $\mathrm{H}$ & $\mathrm{H}$ & $\mathrm{H}$ & $\mathrm{OH}$ & $\mathrm{H}$ & $\begin{array}{l}\text { H. rhamnoides L. subsp. } \\
\text { sinensis }\end{array}$ & {$[23,28]$} \\
\hline 58 & 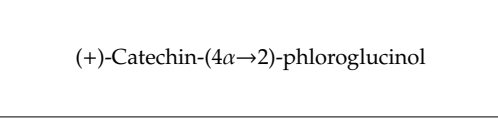 & B & $\mathrm{H}$ & $\mathrm{OH}$ & $\mathrm{H}$ & phloroglucinol & $\mathrm{OH}$ & $\mathrm{H}$ & $\begin{array}{l}\text { H. rhamnoides L. subsp. } \\
\text { rhamnoides cv., H. } \\
\text { rhamnoides L subsp. } \\
\text { sinensis }\end{array}$ & {$[28,36]$} \\
\hline 59 & (-)-Epicatechin & B & $\mathrm{OH}$ & $\mathrm{H}$ & $\mathrm{H}$ & $\mathrm{H}$ & $\mathrm{OH}$ & $\mathrm{H}$ & H. tibetana $\mathrm{S}$. & [34] \\
\hline 60 & (-)-Epicatechin-( $4 \beta \rightarrow 2)$-phloroglucinol & B & $\mathrm{OH}$ & $\mathrm{H}$ & phloroglucinol & $\mathrm{H}$ & $\mathrm{OH}$ & $\mathrm{H}$ & $\begin{array}{l}\text { H. rhamnoides L. subsp. } \\
\text { sinensis }\end{array}$ & [28] \\
\hline 61 & (-)-Epigallocatechin & B & $\mathrm{H}$ & $\mathrm{OH}$ & $\mathrm{H}$ & $\mathrm{H}$ & $\mathrm{OH}$ & $\mathrm{OH}$ & $\begin{array}{l}\text { H. rhamnoides L. subsp. } \\
\text { rhamnoides cv., H. } \\
\text { rhamnoides L. subsp. } \\
\text { sinensis }\end{array}$ & {$[23,36]$} \\
\hline 62 & $(+)$-Gallocatechin & B & $\mathrm{OH}$ & $\mathrm{H}$ & $\mathrm{H}$ & $\mathrm{H}$ & $\mathrm{OH}$ & $\mathrm{OH}$ & $\begin{array}{l}\text { H. rhamnooides L. subsp. } \\
\text { rhamnoides cv., H. } \\
\text { rhamnoides L Lubsp. } \\
\text { sinensis }\end{array}$ & {$[23,36]$} \\
\hline 63 & (+)-Gallocatechin- $(4 \alpha \rightarrow 2)$-phloroglucinol & B & $\mathrm{H}$ & $\mathrm{OH}$ & $\mathrm{H}$ & phloroglucinol & $\mathrm{OH}$ & $\mathrm{OH}$ & $\begin{array}{l}\text { H. rhamnoides } \mathrm{L} \text {. subsp. } \\
\text { rhamnoides cv., H. } \\
\text { rhamnoides } \mathrm{L} \text {. subsp. } \\
\text { sinensis }\end{array}$ & {$[28,36]$} \\
\hline 64 & (-)-Epicatechin gallate & B & $\mathrm{H}$ & 3,4,5-trihydroxybenzoic & $\mathrm{H}$ & $\mathrm{H}$ & $\mathrm{H}$ & $\mathrm{OH}$ & $\begin{array}{l}\text { H. rhamnoides L. subsp. } \\
\text { sinensis }\end{array}$ & [26] \\
\hline 65 & (-)-Gallocatechin gallate & B & $\mathrm{H}$ & 3,4,5-trihydroxybenzoic & $\mathrm{H}$ & $\mathrm{H}$ & $\mathrm{OH}$ & $\mathrm{OH}$ & $\begin{array}{l}\text { H. rhamnoides L. subsp. } \\
\text { sinensis }\end{array}$ & [26] \\
\hline 66 & Naringenin & C & $\mathrm{H}$ & - & - & - & - & - & $\begin{array}{l}\text { H. rhamnoides L. subsp. } \\
\text { sinensis }\end{array}$ & [24] \\
\hline 67 & Naringin & C & Rha-Glc & - & - & - & - & - & $\begin{array}{l}\text { H. rhamnoides L. subsp. } \\
\text { sinensis }\end{array}$ & [24] \\
\hline 68 & 2'-O-Methylisoliquiritigenin & - & - & - & - & - & - & - & H. rhamnoides L. & [37] \\
\hline 69 & Apigenin & - & - & - & - & - & - & - & H. rhamnoides $\mathrm{L}$. & [23] \\
\hline
\end{tabular}




\subsection{Phenolic Acids}

Phenolic acids are the organic acids containing an aromatic ring; these compounds are abundant in Hippophae species in the form of free radicals, or bound as esters and glycosides [27]. Phenolics are the major compounds of Hippophae plants with antioxidant activity [38]. They are divided into hydroxybenzoic acid, hydroxycinnamic acid, and their derivatives, according to the number and position of the hydroxyl and methoxy groups in their aromatic ring. The total phenolic acid content in the seeds of Hippophae species is higher than that in the fruits and seed coat. In a study, the total phenolic acid content in the seeds was released as a soluble ester (57.3\% of the total phenolic acid); free phenolic acid and phenolic acid released by the glycosidic bond accounted for $8.4 \%$ and $34.3 \%$ of the total phenolic acid, respectively [35]. Phenolic acids in Hippophae species mainly include gallic acid, syringic acid, protocatechuic acid, salicylic acid, vanillic acid, gentisic acid, caffeic acid, sinapic acid, ferullic acid, cinnamic acid, 1-feruloyl- $\beta$-D-glucopyranoside and chlorogenic acid [12]. Among them, gallic acid is the predominant phenolic acid in both the fruits and leaves of Hippophae species. The chemical constituents and structures of phenolic acids in Hippophae species are shown in Figure 4 and Table 2.<smiles>[R]c1cc([R])c([R])c([R])c1[R]</smiles><smiles>[C-]#C/C=C/C(=O)OC1CC(O)(C(=O)O)CC(O)C1O</smiles>

Figure 4. Chemical structures of phenolic acids from Hippophae species.

Table 2. Phenolic acids from Hippophae species.

\begin{tabular}{lcccccccc}
\hline No. & Compounds & $\mathbf{R}^{\mathbf{1}}$ & $\mathbf{R}^{\mathbf{2}}$ & $\mathbf{R}^{\mathbf{3}}$ & $\mathbf{R}^{\mathbf{4}}$ & $\mathbf{R}^{\mathbf{5}}$ & \multicolumn{1}{c}{ Species } \\
\hline 70 & Gallic acid & $\mathrm{COOH}$ & $\mathrm{H}$ & $\mathrm{OH}$ & $\mathrm{OH}$ & $\mathrm{OH}$ & H. rhamnoides ssp. turkestanica & [38] \\
\hline 71 & Syringic acid & $\mathrm{COOH}$ & $\mathrm{H}$ & $\mathrm{OMe}$ & $\mathrm{OH}$ & $\mathrm{OMe}$ & H. rhamnoides L. subsp. sinensis & [39] \\
\hline 72 & Protocatechuic acid & $\mathrm{COOH}$ & $\mathrm{H}$ & $\mathrm{OH}$ & $\mathrm{OH}$ & $\mathrm{H}$ & H. rhamnoides ssp. turkestanica & [38] \\
\hline 73 & Salicylic acid & $\mathrm{COOH}$ & $\mathrm{OH}$ & $\mathrm{H}$ & $\mathrm{H}$ & $\mathrm{H}$ & H. rhamnoides ssp. turkestanica & [38] \\
\hline 74 & Vanillic acid & $\mathrm{COOH}$ & $\mathrm{H}$ & $\mathrm{OMe}$ & $\mathrm{OH}$ & $\mathrm{H}$ & H. rhamnoides ssp. turkestanica & [38] \\
\hline 75 & Gentisic acid & $\mathrm{COOH}$ & $\mathrm{OH}$ & $\mathrm{H}$ & $\mathrm{OH}$ & $\mathrm{OH}$ & H. rhamnoides L. subsp. sinensis & [39] \\
\hline 76 & Caffeic acid & $\mathrm{CHCHCOOH}$ & $\mathrm{H}$ & $\mathrm{OH}$ & $\mathrm{OH}$ & $\mathrm{H}$ & H. rhamnoides ssp. turkestanica & [38] \\
\hline 77 & Sinapic acid & $\mathrm{CHCHCOOH}$ & $\mathrm{H}$ & $\mathrm{OMe}$ & $\mathrm{OH}$ & $\mathrm{OMe}$ & H. rhamnoides L. subsp. sinensis & [39] \\
\hline 78 & Ferulic acid & $\mathrm{CHCHCOOH}$ & $\mathrm{H}$ & $\mathrm{OMe}$ & $\mathrm{OH}$ & $\mathrm{H}$ & H. rhamnoides ssp. turkestanica & [38] \\
\hline 79 & Cinnamic acid & $\mathrm{CHCHCOOH}$ & $\mathrm{H}$ & $\mathrm{H}$ & $\mathrm{H}$ & $\mathrm{H}$ & H. rhamnoides ssp. turkestanica & [38] \\
\hline 80 & 1-feruloyl- $\beta$-D-glucopyranoside & $\mathrm{CHCHCOOH-Glu}$ & $\mathrm{H}$ & $\mathrm{H}$ & $\mathrm{H}$ & $\mathrm{OMe}$ & H. rhamnoides L. & [32] \\
\hline 81 & P-hydroxy benzoic acid & $\mathrm{COOH}$ & $\mathrm{H}$ & $\mathrm{H}$ & $\mathrm{OH}$ & $\mathrm{H}$ & H. rhamnoides ssp. turkestanica & [38] \\
\hline 82 & P-coumaric acid & $\mathrm{CHCHCOOH}$ & $\mathrm{H}$ & $\mathrm{H}$ & $\mathrm{OH}$ & $\mathrm{H}$ & H. rhamnoides ssp. turkestanica & [38] \\
\hline 83 & Butylparaben & $\mathrm{COO}(\mathrm{CH})_{3} \mathrm{CH}$ & $\mathrm{H}$ & $\mathrm{H}$ & $\mathrm{H}$ & $\mathrm{H}$ & H. tibetana S. & [34] \\
\hline 84 & Chlorogenic acid & $\mathrm{G}$ & $\mathrm{H}$ & $\mathrm{OH}$ & $\mathrm{OH}$ & $\mathrm{H}$ & H. rhamnoides L. subsp. sinensis & [39] \\
\hline
\end{tabular}

\subsection{Others}

In addition to flavonoids and phenolic acids, Hippophae species contain tannins. Tannins are water-soluble polyphenol compounds found in alkaloids, polysaccharides and proteins with relatively high molecular weight [40]. They can be subdivided into hydrolysable and concentrated tannins. Hydrolyzed tannins include gallic acid esters (gallic acid and ellagic-tannin), and because the molecule has an ester bond and glycosidic bond, it can be hydrolyzed into a small molecule compound and sugar or polyol. Condensed tannins (also known as proanthocyanidins) are polymers of the polyhydroxyflavan-3-alcohol monomer [12]. Their basic structures are formed via the condensation of catechin, (-) epicatechin, and other flavan-3-alcohols or flavan-3,4-glycols at position 4,8- or 4,6 within their carbon-carbon bonds. Tannins isolated from Hippophae species mainly include strictinin, 1,2,6-trigalloylglucose, hyporhamnin, isostrictinin, tellimagrandin I, pedunculagin, hippophaenin A, 
casuaricitin, casuarinin, stachyurin, Hippophaenin B, castalagin and vescalagin. Gossypol, a phenolic aldehyde, was also found in Hippophae species. The chemical constituents and structures of tannins in Hippophae species are shown in Figures 5 and 6, as well as Tables 3 and 4.

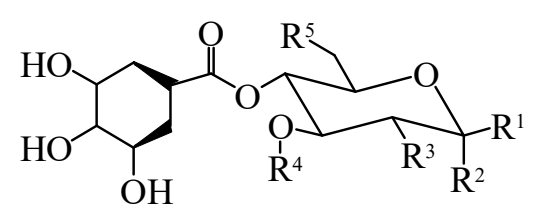<smiles>COc1cc(O)c(O)c(O)c1C1=C(O)C(O)C(O)CC1C(C)O</smiles>

Figure 5. Chemical structures of others from Hippophae species.

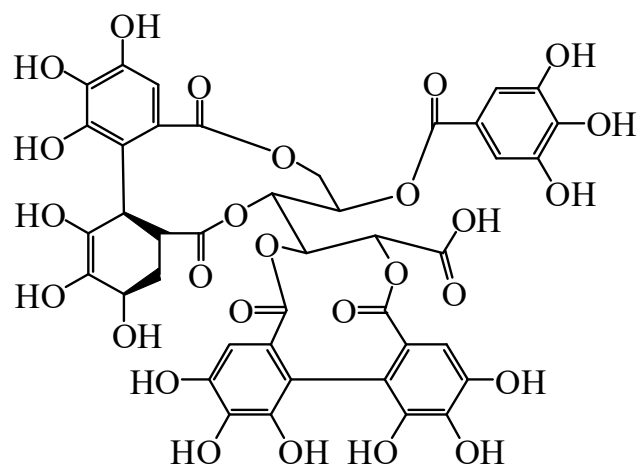

89<smiles>O=C(O)c1cc(O)c(O)c(O)c1O</smiles>

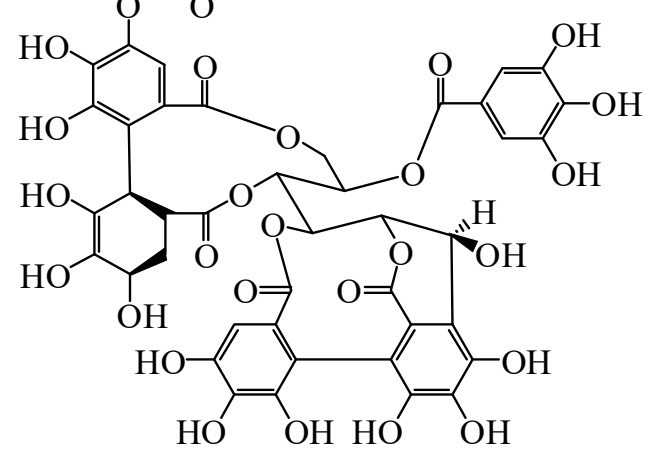

90

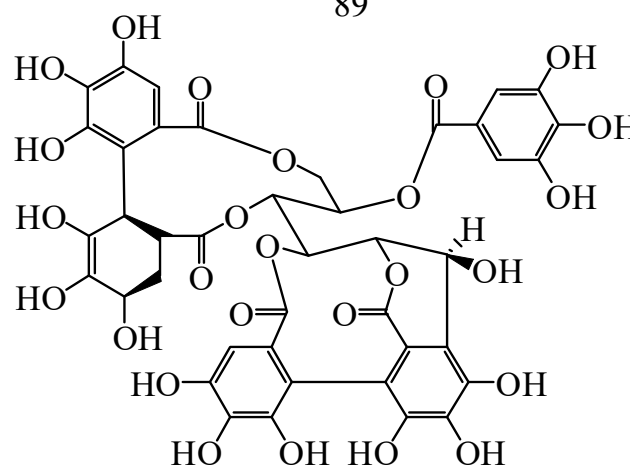

91

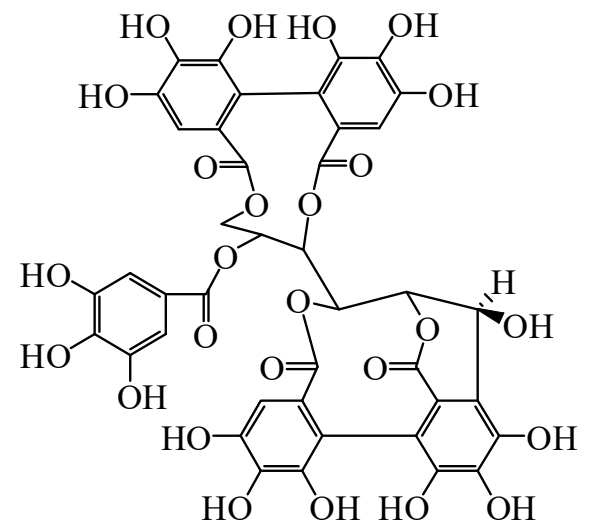

93

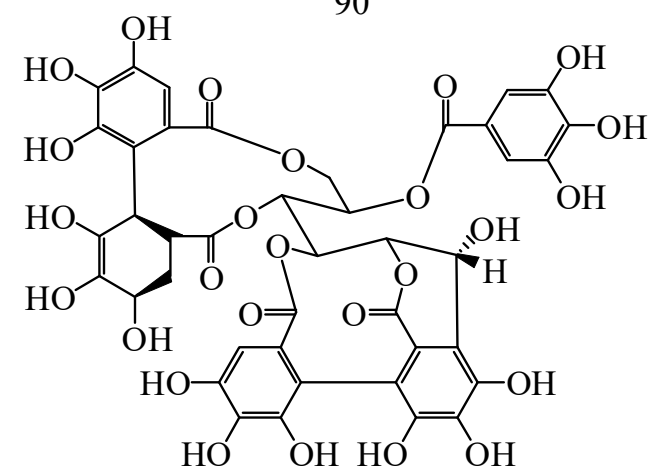

92

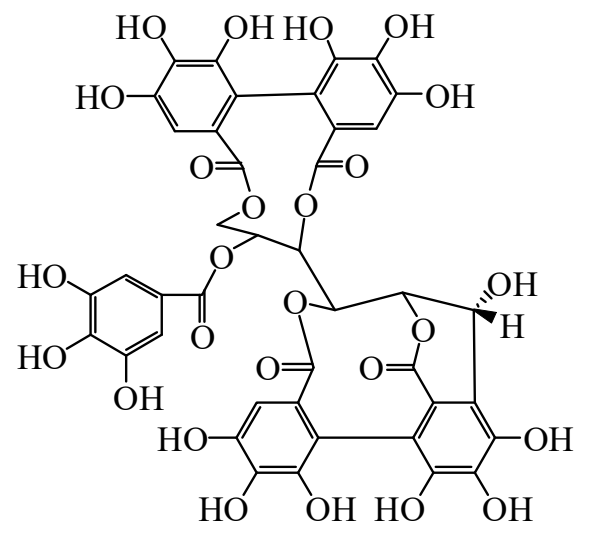

94

Figure 6. Cont. 
<smiles>O=C(OC1OC(CO)C(O)C(O)C(OC(=O)c2cc(O)c(O)c(O)c2)C1c1c(O)c(O)c(O)c(O)c1O)c1cc(O)c(O)c(O)c1</smiles>

95<smiles>O=C(O[C@H]1O[C@H](C(=O)c2cc(O)c(O)c(O)c2)[C@H](O)[C@H](O)[C@H]1OC(=O)c1cc(O)c(O)c(O)c1)c1cc(O)c(O)c(O)c1</smiles>

97

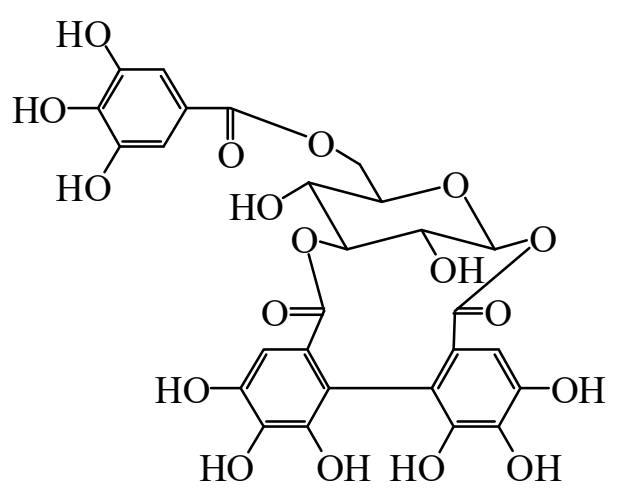

96<smiles>Cc1cc2c(C(C)C)c(O)c(O)c(C=O)c2c(O)c1-c1c(C)cc2c(C(C)C)c(O)c(O)c(C=O)c2c1O</smiles>

98<smiles>O=c1oc2c(O)c(O)cc3c(=O)oc4c(O)c(O)cc1c4c23</smiles>

99

Figure 6. Chemical structures of others from Hippophae species.

Table 3. Others from Hippophae species.

\begin{tabular}{|c|c|c|c|c|c|c|c|}
\hline No. & Compounds & $\mathbf{R}^{1}$ & $\mathbf{R}^{2}$ & $\mathbf{R}^{3}$ & $\mathrm{R}^{4}$ & Species & Ref. \\
\hline 85 & Casuaricitin & O-(3,4,5-trihydroxybenzoic) & $\mathrm{H}$ & \multicolumn{2}{|c|}{ HHDP } & H. rhamnoides L. & {$[41,42]$} \\
\hline 86 & Pedunculagin & $\mathrm{H}$ & $\mathrm{OH}$ & \multicolumn{2}{|c|}{ HHDP } & H. rhamnoides L. & {$[41,42]$} \\
\hline 87 & Strictinin & O-(3,4,5-trihydroxybenzoic) & $\mathrm{H}$ & $\mathrm{H}$ & $\mathrm{H}$ & H. rhamnoides L. & {$[41,42]$} \\
\hline 88 & Tellimagrandi I & $\mathrm{H}$ & $\mathrm{OH}$ & 3,4,5-trihydroxybenzoic & 3,4,5-trihydroxybenzoic & H. rhamnoides $\mathrm{L}$. & {$[41,42]$} \\
\hline
\end{tabular}

Table 4. Others from Hippophae species.

\begin{tabular}{cccc}
\hline No. & Compounds & Species & Ref. \\
\hline 89 & Hippophaenin A & H. rhamnoides L. & {$[42]$} \\
90 & Hippophaenin B & H. rhamnoides L. & {$[42]$} \\
91 & Casuarinin & H. rhamnoides L. & {$[42,43]$} \\
92 & Stachyurin & H. rhamnoides L. & {$[42,43]$} \\
93 & Vescalagin & H. rhamnoides L. & {$[42,43]$} \\
94 & Castalagin & H. rhamnoides L. & {$[42,43]$} \\
95 & Isostrictinin & H. rhamnoides L. & {$[41,42]$} \\
96 & Hyporhamnin & H. rhamnoides L. & {$[42,43]$} \\
97 & 1,2,6-trigalloylglucose & H. rhamnoides L. & {$[41,42]$} \\
98 & Gossypol & H. rhamnoides L. & {$[43]$} \\
99 & Ellagic acid & H. rhamnoides L. subsp. sinensis, H. tibetana S., H. rhamnoides L. & {$[25,43]$} \\
\hline
\end{tabular}




\section{Antioxidant Activity}

Dietotherapy with antioxidant foods is a very convenient and effective method for the supplementation of endogenous antioxidants to alleviate damage due to free radicals [44]. Phenolic compounds are secondary metabolites with antioxidant activity. Their biological activity depends on their structures, combination with other compounds, solubility, absorption and metabolism. The antioxidant mechanisms of polyphenols from Hippophae species (Figure 7) can be summarized as follows.

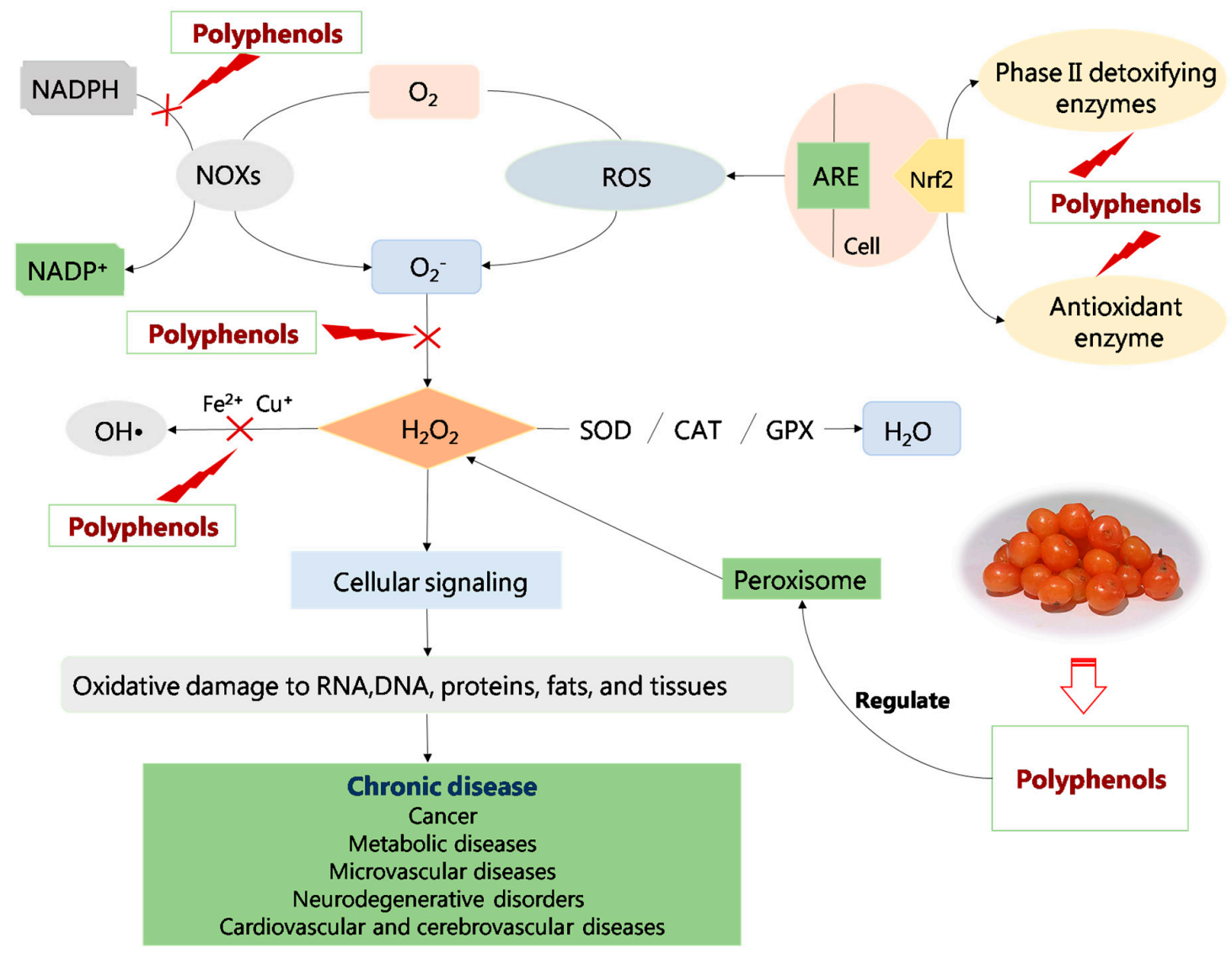

Figure 7. The antioxidant mechanism of polyphenols from Hippophae species. (NADPH: nicotinamide adenine dinucleotide phosphate; $\mathrm{NADP}^{+}$: nicotinamide adenine dinucleotide phosphate; NOXs: NADPH oxidases; SOD: superoxide dismutase; CAT: catalase; GPX: glutathione peroxidase).

\subsection{Regulation of Enzyme Activity}

The enzymes related to free radicals are divided into two categories: oxidase and antioxidant enzymes [45]. An antioxidant effect refers to enhancing the activity of antioxidant enzymes and inhibiting the activity of related oxidase. Among antioxidant enzymes, superoxide dismutase (SOD), glutathione peroxidase (GPX) and catalase (CAT) plays an important role in the induction of reactive oxygen-scavenging enzymes, and glutathione (GSH) synthase can induce the synthesis of endogenous antioxidant enzymes. On the contrary, NADPH oxidase (NOX), xanthine oxidase (XO), lipoxygenase (LOX), monoamine oxidase (MAO) and inducible nitric oxide synthase (iNOS) promote the production of ROS. For example, $\mathrm{XO}$ can catalyze the oxidation of xanthine and hypoxanthine, thus producing peroxide free radicals [46]. Free radicals can be produced by redox and peroxide of transition metal ions (iron and copper). Therefore, promoting antioxidant enzyme production as well as reducing oxidase and metal ion formation can achieve good antioxidant effect. 


\subsubsection{Enhancing Antioxidant Enzyme Activity}

Endogenous antioxidant enzymes include SOD, GPX, CAT, GSH reductase (GR) and glutathione thiotransferase (GST) [47]. SOD is a very effective antioxidant enzyme that converts decomposed superoxide anions into $\mathrm{H}_{2} \mathrm{O}_{2}$ and $\mathrm{O}_{2}$, thereby producing alcohols and water that are harmless to the body. CAT reduces $\mathrm{H}_{2} \mathrm{O}_{2}$ to $\mathrm{H}_{2} \mathrm{O}$ and $\mathrm{O}_{2}$, resulting in free radical detoxification. GPX reduces active peroxide to alcohol and water, whereas GSH is oxidized to glutathione disulfide (GSSG). GSSG is reclaimed into GSH by GR. GR is the main enzyme maintaining the glutathione redox state. GST is generally regarded as a 2-phase enzyme, which mainly exists in electrophilic compounds for detoxification [48]. Several studies have also shown that GST can catalyze the decomposition of the lipid hydrogen peroxide produced by oxidative damage of lipid molecules.

Wang et al. treated rabbits with the total flavones from H. rhamnoides L. (sea buckthorn) for 2 weeks pre-light exposure and 1-week post-light exposure until sacrifice. The rabbit's retinal function was assessed by an electroretinogram 1 day before light exposure and on days 1, 3 and 7 post-light exposure. On the seventh day after light exposure, the thickness of the extraretinal nuclear layer and TUNEL were measured to evaluate the degree of retinal degeneration. Western blotting analysis, enzyme-linked immunosorbent assay and immunohistochemistry were used to investigate the antioxidant mechanisms of the total flavones from sea buckthorn in the process of the retinal degeneration induced by visible light. The total flavones from sea buckthorn ameliorated the retinal oxidative stress induced by light exposure, as determined by the measurements of glutathione peroxidase (GSH), CAT, total antioxidant capacity (T-AOC) and malonaldehyde (MDA). Moreover, the activities of GSH and CAT in the retinal injury model group were significantly lower than those in the control group $(p<0.05)$. Overall, the results of this study revealed that total flavones from sea buckthorn have antioxidant effects and indirectly inhibit retinal cell apoptosis [49].

Zhang et al. used Caenorhabditis elegans as a model organism to investigate the antiaging effects and mechanism of sea buckthorn seed extract. The samples were prepared using ethanol extraction and macroporous resin purification. The effects of different concentrations of sea buckthorn seed extract on the oxidative stress defense of $C$. elegans were studied. To explore the antiaging mechanism of sea buckthorn seed extract at the gene level, antioxidant enzyme activity and related gene expression were studied. The results showed that sea buckthorn seed extract significantly reduced oxidative stress $(p<$ 0.05). In addition, sea buckthorn seed extract increased the activity of SOD, CAT and GSH. The activity of SOD and CAT was significantly higher in the sea buckthorn seed extract-treated group than in the control group. It was concluded that sea buckthorn seed extract improves the activity of antioxidant enzymes, and thus has an antiaging effect [50].

An in-vivo study investigated the antioxidant activities of the phenolic-rich fraction (PRF) of sea buckthorn leaves on oxidative stress induced by $\mathrm{CCl}_{4}$ in Sprague-Dawley rats. The total phenol content was $319.33 \mathrm{mg} \mathrm{GAE} / \mathrm{g}$ PRF, and the amounts of gallic acid, isorhamnetin, quercetin, myricetin and kaempferol were in the range of $1.935-196.89 \mathrm{mg} / \mathrm{g}$, as determined by reverse-phase high-performance liquid chromatography. PRF had a protective effect on liver lipid peroxide, hydrogen peroxide, protein carbonylation, liver GSH decrease and liver antioxidant enzyme (SOD, CAT, GPX, GR, GST) activity induced by $\mathrm{CCl}_{4}$. The data obtained in this study suggested that PRF exerts strong antioxidant activity, prevents oxidative damage of main biomolecules, and protects the liver from $\mathrm{CCl}_{4}$-induced oxidative damage [48].

\subsubsection{Inhibiting the Production of Oxidase}

Inducible nitric oxide synthase (iNOS) overexpression leads to the production of a large amount of NO. Under normal conditions, NO has both neuroprotective and neurotoxic effects. Excessively high concentration of endogenous and exogenous $\mathrm{NO}$ will lead to the production of $\mathrm{OH} \bullet$ and nitrogen dioxide free radicals in large quantities, thus causing damage to proteins, nucleic acids and cell membranes, accelerating mitochondrial damage and promoting cell apoptosis [51,52]. Therefore, inhibition of iNOS expression and the reduction of NO concentration can significantly increase 
antioxidant capacity and decrease oxidative stress injury. Yang's research provided evidence that sea buckthorn fruit is an important inhibitor of nitric oxide [53].

This study reported the antioxidant effect of sea buckthorn on C6 glioma cells with induced hypoxia. Cytotoxicity as well as nitric oxide and ROS production increased significantly after $12 \mathrm{~h}$ of cellular exposure to hypoxia, compared to that in the control group. This resulted in decreased intracellular antioxidant levels and glutathione/oxidized glutathione ratio. The results showed that sea buckthorn pretreatment has a significant inhibitory effect on the production of ROS and nitric oxide induced by hypoxia, showing strong antioxidant activities [54]. It has also been shown that the antioxidant indices of sea buckthorn flavonoids in aging rats induced by D-galactose include monoamine oxidase (MAO) and nitric oxide (NO), in addition to related antioxidant enzymes. The results showed that $H$. rhamnoides L. flavonoids increased the level of related antioxidant enzymes and decreased MAO activity $(p<0.05)$ and NO content $(p<0.05)$ in rats. This study provided evidence of the antioxidant activity of sea buckthorn [55].

Plasma iron and copper are catalysts of many free radical synthetic reactions; especially, iron ions catalyze lipid peroxidation and free radical synthesis. Polyphenols can bond with free metal ions. For example, the catechol structure of the quercetin molecule can bind with $\mathrm{Fe}^{2+}$ or $\mathrm{Cu}^{2+}$ to form inactive metal complexes, which can reduce oxidation reactions and the damage caused by free radicals to the body [56,57]. In a study, the antioxidant effects of aqueous and hydroalcoholic extracts of sea buckthorn leaves were studied using reversed-phase high-performance liquid chromatography. The total phenol content and total flavonoid content of the leaf extracts was determined by colorimetric analysis. The reducing potential of aqueous and hydroalcoholic sea buckthorn leaf extracts were determined using a modified iron (III) to iron (II) reduction assay. The $\mathrm{Fe}^{3+} /$ ferricyanide complex can be reduced to its ferrous form by the addition of a reducing agent to the solution. Therefore, the addition of Perls' Prussian blue to the solution creates an insoluble complex with iron (II) that can be measured as a precipitate [58]. The reducing potential of hydroalcoholic sea buckthorn leaf extract is lower than that of ascorbic acid, and higher than that of aqueous sea buckthorn leaf extract. In addition, the reductive activity of each extract was determined to be concentration-dependent. The antioxidant activity of the sea buckthorn extracts was determined using ABTS, DPPH and ferric reducing/antioxidant power (FRAP) assays. The results indicated that both the aqueous and hydroalcoholic sea buckthorn extracts had significant antioxidant activity [59]. Ting et al. induced oxidative stress in mice with carbon tetrachloride $\left(\mathrm{CCl}_{4}\right)$, and then treated them with sea buckthorn seed oil to study the in vitro and in vivo antioxidant capacity of the seed oil. In this study, the ferrous ion chelating ability of the seed oil was determined by reduction of absorbance at $562 \mathrm{~nm}$. The results of a quantitative colorimetric assay revealed that sea buckthorn seed oil at concentrations of $0.92-18.3 \mathrm{mg} / \mathrm{mL}$ chelated $7.74 \%-38.5 \%$ of ferrous ions. It was indicated that the sea buckthorn seed oil has a good iron-chelating effect, and has a certain protective effect against oxidative damage [60]. However, it should be pointed out that from the physiological perspective, in-vitro testing of the FRAP reaction in plasma may not reflect the actual physiological structure or activity of the body. Currently, clinical studies are needed to measure and compare changes in FRAP values in relation to specific pathological conditions according to different populations, as well as to monitor FRAP values under different treatment strategies. Despite the limitations, the FRAP experiment appears to be an attractive and potentially useful test. The results are highly reproducible over a wide concentration range. In conclusion, the FRAP experiment can potentially be an effective indicator of antioxidant defense in oxidative stress and related studies $[61,62]$.

\subsection{Effects on Cell Antioxidant Responses}

Nuclear factor erythroid 2-related factor 2 (Nrf2) is a key transcription factor of the cellular antioxidative stress system [63]. Moreover, Nrf2 nuclear translocation combined with antioxidative response element antioxidant responsive element (ARE) on the nucleic acid sequence is a key link in the activation of Nrf2-ARE signaling pathways [64]. Currently, the Nrf2/ARE signaling pathway appears to be the most important endogenous antioxidant stress pathway $[65,66]$. Furthermore, Nrf2 is pivotal 
in the host defense mechanism, and numerous key phase II enzymes, such as NQO1 and HO-1 [67], are controlled by Nrf2 transcription factor under ROS conditions [4].

Research has been conducted on paraquat (PQ)-exposed A549 cells to evaluate the antioxidant effects of $H$. rhamnoides L. (sea buckthorn) extract to determine whether sea buckthorn extract induces the expression of Nrf2, its downstream target genes, and other antioxidant-related genes, including Nrf2 target genes, such as NQO1 and HO-1, and phase II detoxifying genes, including GPx1, GSR, SOD1, CAT, PRDX1 and LPO [68]. The results showed that pretreatment of A549 cells with sea buckthorn extract (25-200 $\mu \mathrm{g} / \mathrm{mL})$ significantly attenuated PQ $(200 \mu \mathrm{M})$-induced cellular toxicity. Moreover, sea buckthorn extract was shown to effectively induce Nrf2 gene expression in a concentration-dependent manner, which significantly contributed to protection against PQ-induced cell death. Notably, Nrf2 expression was markedly induced by sea buckthorn treatment only. In addition, the accumulation of Nrf2 was observed following treatment with sea buckthorn extract. Flavonoid compounds present in the sea buckthorn extract may be involved in the activation of Nrf2, as it has been shown that synthetic flavonoid compounds are potent inducers of the ARE/Nrf2/Keap1 signaling pathway [69]. Based on these results, it was hypothesized that sea buckthorn extract may be used as a potential therapeutic agent for the treatment of various oxidative stress-related diseases.

Studies have shown that Nrf2 is also a major regulator that modulates the expression of the phase II detoxifying enzymes SOD and GPx [70]. Induction of phase II enzymes that neutralize reactive electrophiles and act as indirect antioxidants is an important mechanism of protection against many diseases [71]. The antioxidant effect and action mechanism of H. rhamnoides L. (sea buckthorn) leaf tea extracts have been reported in $\mathrm{H}_{2} \mathrm{O}_{2}$-induced murine RAW264.7 macrophages (RAW264.7 cells). The results showed that sea buckthorn leaf tea extracts $(40 \mu \mathrm{g} / \mathrm{mL})$ protected RAW264.7 cells from $\mathrm{H}_{2} \mathrm{O}_{2}$ ( $5 \mathrm{mM}$ )-induced damage. Cells incubated with sea buckthorn leaf tea extracts showed significantly $(p<0.05)$ elevated SOD and GPx activities, compared with $\mathrm{H}_{2} \mathrm{O}_{2}$-treated controls. The analyses showed that sea buckthorn leaf tea extracts also upregulated the expression of Nrf2; the activation of the Nrf2/ARE antioxidant signaling pathway might play an important role in rescuing cell viability. However, further research is necessary to determine whether elevated Nrf2 expression results in an increase in antioxidant enzyme activity [17].

Furthermore, the antioxidant effect of dietary H. rhamnoides L. (sea buckthorn) pomace in ram testis and epididymis was investigated. Rams received diet containing different levels of sea buckthorn pomace $(0 \%, 10 \%, 20 \%$ and $30 \%)$ for 65 days. Testis and epididymis samples were collected, and the mRNA and protein expression of antioxidant enzymes was detected. The results showed that supplementation of $20 \%$ sea buckthorn pomace reduced the mRNA expression of GPx 4 in the testis, $\mathrm{Cu}-\mathrm{ZnSOD}$ and GPx4 in the caput epididymis, CAT in the corpus epididymis, and Cu-ZnSOD in the cauda epididymis, as well as the protein expression of Nrf2 in the caput epididymis and Cu-ZnSOD in the cauda epididymis [72].

\subsection{Others}

In addition to the mechanisms mentioned above, lipid peroxidation and free radical-scavenging activity have also been identified as antioxidant mechanisms of sea buckthorn phenolic compounds.

Lipid peroxidation is mainly caused by ROS. A free radical chain reaction occurs in the biological membrane phosphatide and initiates propagation reactions, which lead to the damage of erythrocyte membranes and consequently, hemolysis [73,74]. In biological systems, lipid peroxidation produces many aldehydes, among which MDA is the most important indicator of lipid peroxidation. Lipid peroxidation can decrease cell membrane fluidity, inactivate membrane binding proteins, and create cytotoxic aldehydes, such as malondialdehyde or 4-hydroxynonenal. Water-soluble peroxides may react with metals to produce other kinds of free radicals, which can also cause membrane damage [48]. Recent studies have suggested that sea buckthorn has a potent inhibitory effect on lipid peroxidation [75]. This effect might be attributed to its high polyphenolic compound content [76]. In a study, Sprague-Dawley rats were pretreated with the total flavonoid from sea buckthorn by gavage, 
and then subjected to myocardial ischemia-reperfusion injury induction. The results showed that after $40 \mathrm{~min}$ of ischemia and $30 \mathrm{~min}$ of reperfusion, the total flavonoids significantly reduced pathological changes in the ultrastructure of the ischemia-reperfusion injury area, significantly improved SOD activity in rat cardiac tissue, and reduced MDA generation.

All these results indicated that the total flavonoids significantly reduced the lipid peroxidase metabolite MDA and inhibited lipid peroxidation in vivo. This inhibitory effect may be caused by the direct scavenging effect on $\mathrm{O}_{2}$, suggesting that the total flavonoids provide protection from myocardial ischemia-reperfusion injury by increasing the free radical-scavenging enzyme and inhibiting lipid peroxidation [77]. Liu [78] observed the effect of sea buckthorn extract on lipofuscin in the brain tissue, and lipid peroxidation (via measurement of the MDA level) in the serum of elderly Wistar rats after administration of the extract for 30 days. The results showed that lipofuscin and MDA content in the experimental group was lower than that in the control group. The reason may be that the sea buckthorn extract contained SOD with high activity, which can metabolize lipid peroxide into hydroxyl compounds to protect cells from peroxidative damage.

Free radicals are extremely active, and are also unstable groups of atoms that constantly seize electrons from other atoms for stability, causing an oxidation reaction. Normal biological oxidation and the resulting free radicals can benefit the body by regulating signal transduction between cells, regulating cell formation, inhibiting the viruses and bacteria that enter the body, and preventing infection. Ideally, the concentration of free radicals in the body are maintained in a state of equilibrium by balancing the formation and elimination of free radicals. However, this balance is difficult to maintain owing to disruption by the body's own bodily activities, emotional fluctuations, and various external environmental factors [79]. Polyphenol compounds can remove free radicals by acting as an electron donor, thus preventing tissue damage caused by free radicals and peroxides [80]. Su [81] studied the antioxidant capacity of ethanol extracts from sea buckthorn berries; the antioxidant capacity was comprehensively investigated by 2,2-azinobis-(3-ethylbenzothiazole-6-sulfonate, nitrogen radical cation) (ABTS) radical-scavenging activity in vitro. The results showed that the ethanol extract of sea buckthorn had a good scavenging effect on ABTS free radicals. At a concentration of $5 \mathrm{mg} / \mathrm{mL}$, the ABTS-scavenging ability of the extract was similar to that of the positive control butylated-hydroxy-toluene (BHT) at $5 \mathrm{mg} / \mathrm{mL}$. In addition, Varshneya evaluated the antioxidant activity of $100 \%$ methanolic extract (ME), 70\% aqua-methanolic extract (AME) and $100 \%$ aqueous extract of the sea buckthorn by-product. The total phenolic content in AME was significantly higher than that in other extracts. All extracts scavenged different radicals in vitro in a concentration-dependent manner. AME had the lowest $\mathrm{IC}_{50}$ values for ABTS, 2,2-diphenyl-1-picrylhydrazyl, superoxide and nitric oxide radicals, whereas $\mathrm{ME}$ had the lowest values for hydroxyl radicals. The reducing power of the extracts increased in a concentration-dependent manner, with AME showing the highest reducing power [82].

However, at present, evaluation of free radical-scavenging activity has been focused in vitro, such as in cell models. Moreover, animal studies on this activity and its mechanisms are not in-depth. A commonly used method to evaluate free radical-scavenging activity is the DPPH assay; however, this assay does not provide meaningful information on the actual reactivity of an antioxidant [63]. Some studies have pointed out that free radical-scavenging activity is ineffective in vivo; thus, further studies are necessary [83]. Table 5 shows recent studies on the mechanism of the antioxidant activities of phenolic acids in Hippophae species. 
Table 5. Antioxidant activities of phenolic acids in Hippophae species.

\begin{tabular}{|c|c|c|c|c|}
\hline Ingredients & Model & Treatment & Results & Ref. \\
\hline Apigenin & Sprague-Dawley rats & 10,15 and $20 \mathrm{mg} / \mathrm{kg}$ & Apigenin significantly reduced the lipid hydroperoxides and increased the total antioxidant levels. & [84] \\
\hline Quercetin & Streptozotocin (STZ)-induced diabetes in rats & $15 \mathrm{mg} / \mathrm{kg} / \mathrm{d}$ & $\begin{array}{l}\text { Quercetin plays a protective role by reducing lipid peroxidation, NO production and increasing } \\
\text { antioxidant enzyme activity. }\end{array}$ & [85] \\
\hline Isorhamnetin & Carrageenan-induced paw edema in Sprague-Dawley rats & 10 or $30 \mathrm{mg} / \mathrm{kg}$ & $\begin{array}{l}\text { The induction of Ho-1 by isorhamin can reduce the production of ROS and significantly increase the } \\
\text { nuclear level of Nrf2. }\end{array}$ & [86] \\
\hline Kaempferol & Sprague-Dawley rats & $15 \mathrm{mmol} / \mathrm{L}$ & $\begin{array}{l}\text { Kaempferol significantly increased SOD activity and GSH/GSSG ratio, while significantly reduced } \\
\text { MDA level. }\end{array}$ & [87] \\
\hline Myricetin & Human MCF-7 breast cancer cells & $0.0,0.05,0.1$ and $0.2 \mu \mathrm{mol}$ & Myricetin decreased ferric ions and cellular ROS, respectively. & [88] \\
\hline Naringenin & Ethanol-induced rats & $50 \mathrm{mg} / \mathrm{kg}$ & $\begin{array}{l}\text { Naringenin elevated the activities of SOD and catalase in the tissues of ethanol-treated rats, inhibit } \\
\text { malondialdehyde and to scavenge hydroxyl groups, increased the activities of GR, GPx and GST. }\end{array}$ & [89] \\
\hline Naringin & Isoproterenol (ISO)-induced myocardial infarction (MI) in rats & $10,20,40 \mathrm{mg} / \mathrm{kg}$ & $\begin{array}{l}\text { Naringin saw a significant decrease in the levels of lipid peroxidative products and improved the } \\
\text { antioxidant status by increasing the activities of antioxidant enzymes and nonenzymatic antioxidants. }\end{array}$ & [90] \\
\hline Hyperoside & Hydrogen peroxide-induced V79-4 cells & $1,2.5$ and $5 \mu \mathrm{mol}$ & $\begin{array}{l}\text { Hyperoside was shown to possess cytoprotective properties against oxidative stress by scavenging } \\
\text { intracellular ROS and enhancing the catalase and glutathione peroxidase activities. }\end{array}$ & [91] \\
\hline (+)-Catechin & Mature male Wistar rats were given chlorpyrifos & $20 \mathrm{mg} / \mathrm{kg}$ & $\begin{array}{l}\text { Catechin statistically significantly decreased MDA levels, SOD and CAT activities, while increased } \\
\text { GPx and GST activities. }\end{array}$ & [92] \\
\hline Rutin & Streptozotocin (STZ)-induced diabetic rats & $100 \mathrm{mg} / \mathrm{kg}$ & $\begin{array}{l}\text { Rutin improved the antioxidant status of diabetic rats by decreasing lipid peroxidative products and } \\
\text { increasing enzymic and nonenzymic antioxidants. }\end{array}$ & [93] \\
\hline Gallic acid & Streptozotocin-induced diabetic male Wistar rats & 10 and $20 \mathrm{mg} / \mathrm{kg}$ & Gallic acid significant increasing lipid hydroperoxides, SOD, CAT, GPx activities. & [94] \\
\hline Syringic acid & Nephrotoxicity was induced in male Wistar albino rats by the administration & $50 \mathrm{mg} / \mathrm{kg}$ & Syringic acid increased GPx, CAT and SOD activities of renal tissue. & [95] \\
\hline Vanillic acid & $\begin{array}{l}\text { Oral squamous cell carcinomas were induced in each hamster's buccal pouch } \\
\text { (left side only) }\end{array}$ & $200 \mathrm{mg} / \mathrm{kg}$ & $\begin{array}{l}\text { Vanillic acid significantly restored the SOD, CAT, GPx, GSH, vitamin E, vitamin C to near normal } \\
\text { range in DMBA-treated hamsters. }\end{array}$ & [96] \\
\hline Chlorogenic acid & Intestinal mitochondrial injury by $\mathrm{H}_{2} \mathrm{O}_{2}$ & $0,20,40,80$, and $160 \mu \mathrm{mol} / \mathrm{L}$ & $\begin{array}{l}\text { Chlorogenic acid decreased } \mathrm{H}_{2} \mathrm{O}_{2} \text {-induced } \mathrm{ROS} \text { production in a dose-dependent manner, } \\
\text { and T-AOC, SOD and GSH activities were also increased. }\end{array}$ & [97] \\
\hline Ferulic acid & Streptozotocin-induced diabetic rats & 10 and $20 \mathrm{mg} / \mathrm{kg}$ & $\begin{array}{l}\text { Ferulic acid effectively inhibited the lipid peroxidation and elevated the catalase, superoxide } \\
\text { dismutase, glutathione and nitric oxide levels. }\end{array}$ & [98] \\
\hline
\end{tabular}




\section{Application}

The fruits and leaves of Hippophae species are rich in various bioactive components and nutritional ingredients, which are useful in the fields of healthcare, the food industry and the cosmetic industry. In recent years, researchers in the fields of nutrition, food science, medicine, sports science, agriculture and forestry have performed numerous studies on Hippophae species, supporting its use as a medicine and food. They believe that the leaves, fruits and seeds of Hippophae plants will become ideal high-grade raw materials of nutritious health food with great ecological, social and economic benefits.

\subsection{Medicinal Values of Hippophae Species}

Studies performed worldwide have found that Hippophae species contain rich biologically active components that have important medicinal effects on human health; thus, these species are referred to as "vitamin storehouses" and "mystery fruits" [99]. They have been widely used in the field of medicine, and scientific interest in Hippophae species as therapeutic agents is rapidly increasing. Guo [100] developed a fermentation method to enhance the active substances with the intestinal autoimmunity function found in $H$. rhamnoides L. leaves, in which beneficial bacteria is firmly wrapped using a drying technique, thereby enabling it to reach the intestine and exert antioxidant effects. Li [101] formulated a hepatoprotective natural product from H. rhamnoides L. by inoculating mixed strains of yeasts and lactic acid bacteria to composite culture medium, which was then subjected to a closed culture to obtain a strain solution. The solution was then mixed with $H$. rhamnoides $\mathrm{L}$. and subjected to closed fermentation before elution to obtain the hepatoprotective natural product. The final product contains a large number of active components of detoxification and antioxidant reactions in the liver, and has the following beneficial effects: oxidation resistance, free radical-scavenging, chemical liver injury repair-promoting and liver function-improving effects.

\subsection{Food Values of Hippophae Species}

The fruit of Hippophae species is called a third-generation fruit. Hippophae plants contain more than 100 types of compounds; this includes vitamin C content of up to $25 \mathrm{mg} / \mathrm{g}$ [35]. As of 2018, there have been more than 200 kinds of products derived from Hippophae species, including nonalcoholic beverages, wines, jams, ice creams, candies and natural additive pigments [102]. Zou [103] applied for a patent for the H. rhamnoides L. fruit peel powder, which is rich in antioxidant nutrients, as a nutritional supplement that can significantly enhance the body's free radical-scavenging function and improve antioxidant function in immunocompromised people or people with antioxidant hypofunction. Yan [104] provided a health-promoting edible salt product of $H$. rhamnoides L. that has high nutritional value and exerts excellent antioxidant effects; this product also has a unique taste and is additive-free.

\subsection{Cosmetic Values of Hippophae Species}

Cosmetics made from Hippophae plant extracts have been produced abroad; these products have natural skin-nourishing and hair-protecting properties. Cosmetic products made of Hippophae plants include shampoo, skin cream and bath soak [102]. Smida [105] evaluated the antioxidant activities of sea buckthorn-based mouthwash; the free radical-scavenging activity of sea buckthorn was assessed by DPPH and superoxide anion scavenging (NBT) assays to elucidate the role of sea buckthorn in reducing oxidative stress and damage linked to periodontitis. The results suggested that the superoxide radical-scavenging activities of the sea buckthorn pulp oil-based mouthwash increased markedly with increasing concentrations, suggesting that the mouthwash is a potent scavenger of superoxide radicals. Furthermore, numerous beauty care products derived from $H$. rhamnoides L., such as hair lotions, moisturizing creams, facial creams and facial masks, are popular in Russia [106]. 


\section{Conclusions}

In recent years, considering the frequent use of Hippophae species in traditional Chinese medicine, it is necessary to explore polyphenols more comprehensively. This paper systematically reviewed the composition and antioxidant activity of polyphenols in Hippophae species, and provided a basis for the further development and utilization of resources from Hippophae species. Although phytochemical and pharmacological studies of Hippophae species have made great progresses, there are still many problems in the research and development of Hippophae species.

Firstly, there are many subspecies of Hippophae plants, which indicates differences in chemical composition among Hippophae subspecies; however, there is no systematic study of Hippophae subspecies. Secondly, although there are many studies on the chemical constituents of Hippophae species, there are few studies on their antioxidant pharmacology at the level of chemical monomers, and the material basis of their pharmacological effect is not clear. Through literature study on the antioxidant activity of Hippophae, it was found that the DPPH assay is used in a large proportion of experiments verifying the antioxidant activities of Hippophae. However, some studies have shown that the kinetic analysis of DPPH as an antioxidant activity test has been questioned; especially, the significance of antioxidants detected by DPPH in the human body needs to be further confirmed [63]. In addition, the establishment of animal models has greatly contributed to the development of medicines. However, despite the similarities, there are still some differences between humans and animals. Whether the same drug would have the same effect in humans as in animals remains to be elucidated. Therefore, in vitro and animal experiments should be conducted in drug studies to provide a foundation for further development in clinical research [107]. Thirdly, H. rhamnoides L. oil and flavonoids are of great demand in the market, but their finished products have poor stability and low purity, limiting their further development and utilization; therefore, other parts of $H$. rhamnoides L. with medicinal values need to be further studied [26].

Our review showed that Hippophae species are important plants containing valuable chemicals and important nutrients, and thus can be marketed commercially as alternative sources of nutrition. The commercial and ecological potential of Hippophae species can improve people's living standards and protect the environment. A large amount of experimental data showed that Hippophae species have important activity and numerous biologically active substances. Therefore, Hippophae species are precious sources of important substances and nutrients with a broad market potential [8].

Author Contributions: M.L., X.G., and M.J. conceived and designed the study; M.J., X.G., X.L., and C.W. Contributed significantly to the design of the paper, edited and wrote some portion of the paper, compiled the references and analyzed the data; M.H., X.G., and M.J. wrote the manuscript; All authors have read and agreed to the published version of the manuscript.

Funding: This research was funded by National Natural Science Foundation of China (No. 81760776), National Natural Science Foundation of China (No. 81874336), Natural Science Foundation of Inner Mongolia (No. 2018ZD13), Agriculture Research System of China (No.CARS-21), 2018 Chinese medicine public health service subsidy special "the fourth national survey of Chinese materia medica resources" (No. Finance Society [2018] 43).

Conflicts of Interest: The authors declare no conflict of interest.

\section{References}

1. Xu, D.P.; Li, Y.; Meng, X.; Zhou, T.; Zheng, J.; Zhang, J.J.; Li, H.B. Natural Antioxidants in Foods and Medicinal Plants: Extraction, Assessment and Resources. Int. J. Mol. Sci. 2017, 18, 96. [CrossRef]

2. Yang, L.B.; Jia, M.; Liu, S.J.; Diao, Y.B.; Zhang, Y.Q.; Xiao, Q.R. Anti-oxidation effect of the Shaji Tablet on mice. Hebei Med. J. 2015, 37, 649-651. [CrossRef]

3. Saikia, M.; Handique, P.J. Antioxidant and antibacterial activity of leaf, bark, pulp and seed extracts of seabuckthorn (Hippophae salicifolia D. Don) of Sikkim Himalayas. J. Med. Plants Res. 2013, 7, 1330-1338.

4. Liu, Y.; Sun, W.; Liu, C.; Zhang, Y.Q.; Chen, Y.L.; Song, M.; Fan, G.; Liu, X.; Xiang, L.; Zhang, Y. Identifcation of Hippophae species (Shaji) through DNA barcodes. Chin. Med. 2015, 10, 28. [CrossRef] 
5. Wang, W.J. Effect of Seabuckthorn Protein on Lipid Metabolism and Intestinal Microbial Community in Streptozotocin-Induced Diabetic Mice. Master's Thesis, Hefei University of Technology, Hefei, China, 2017. [CrossRef]

6. Lu, R.S. Research on seabuckthorn (Hippophae L.) resources in China. Acta. Hortic. Sin. 1990, 17, 177-183, 248.

7. Du, J.; Xi, Y.L.; Song, C.M. Effect of Sea Buckthorn Powder on Hepatic Lipid Metabolism and Oxidative Stress in Rats. Mod. Food Sci. Technol. 2017, 33, 8-12, 133. [CrossRef]

8. Di Mauro, M.D.; Giardina, R.C.; Fava, G.; Mirabella, E.F.; Acquaviva, R.; Renis, M.; D’Antona, N. Polyphenolic profile and antioxidant activity of olive mill wastewater from two Sicilian olive cultivars: Cerasuola and Nocellara etnea. Eur. Food Res. Technol. 2017, 243, 1895-1903. [CrossRef]

9. Di Mauro, M.D.; Fava, G.; Spampinato, M.; Aleo, D.; Melilli, B.; Saita, M.G.; Centonze, G.; Maggiore, R.; D'Antona, N. Polyphenolic fraction from olive mill wastewater: Scale-up and in vitro studies for ophthalmic nutraceutical applications. Antioxidants 2019, 8, 462. [CrossRef]

10. Acquaviva, R.; Sorrenti, V.; Santangelo, R.; Cardile, V.; Tomasello, B.; Malfa, G.; Vanella, L.; Amodeo, A.; Genovese, C.; Mastrojeni, S.; et al. Effects of an extract of Celtis aetnensis (Tornab.) Strobl twigs on human colon cancer cell cultures. Oncol. Rep. 2016, 36, 2298-2304. [CrossRef]

11. Wani, T.A.; Wani, S.M.; Ahmad, M.; Gani1, A.; Masoodi1, F.A. Bioactive profile, health benefits and safety evaluation of sea buckthorn (Hippophae rhamnoides L.): A review. Cogent. Food. Agric. 2016, 2, 1128519. [CrossRef]

12. Singh, B.; Singh, J.P.; Kaur, A.; Singh, N. Phenolic composition and antioxidant potential of grain legume seeds: A review. Food Res. Int. 2017, 101, 1-16. [CrossRef] [PubMed]

13. Lian, Y.S.; Wan, L. Types of bioactivity substances of genus Hippophae L. and their functions in physiology and pharmacology. Hippophae 2007, 20, 1-12.

14. Du, L.L.; Chen, W.; Li, Y.Z.; Wang, X.Y. Determination of the polyphenols in berries of Hippophae rhamnoides subsp. wolongensis. West. Chin. J. Pharm. Sci. 2015, 30, 336-338. [CrossRef]

15. Li, J.X.; Wang, B.Y. Folin-ciocalteu colorimetric determination of total polyphenols in mulberry fruits. Food Sci. 2009, 30, 292-295. [CrossRef]

16. Fredes, C.; Montenegro, G.; Zoffoli, J.P.; Santander, F.; Robert, P. Comparison of the total phenolic content, total anthocyanin content and antioxidant activity of polyphenol-rich fruits grown in Chile. Cienc. Investig. Agrar. 2014, 41, 9-10. [CrossRef]

17. Cho, H.; Cho, E.; Jung, H.; Yi, C.H.; Lee, B.; Hwang, K.T. Antioxidant activities of sea buckthorn leaf tea extracts compared with green tea extracts. Food Sci. Biotechnol. 2014, 23, 1295-1303. [CrossRef]

18. Lv, Q.; Tu, Y.H.; Li, J.; Liu, H.T.; Zhang, R.Q.; Luo, Y.; Kang, Y.Q. Comparative Study on Content of Tea Polyphenols Extracted from Different Tea Plant Tissue. J. Guiyang Med. Coll. 2016, 41, 265-267. [CrossRef]

19. Zu, Y.; Li, C.; Fu, Y.J.; Zhao, C.J. Simultaneous determination of catechin, rutin, quercetin kaempferol and isorhamnetin in the extract of sea buckthorn (Hippophae rhamnoides L.) leaves by RP-HPLC with DAD. J. Pharm. Biomed. Anal 2006, 41, 714-719. [CrossRef]

20. Cao, F.; Chen, G.R.; Wang, A.G. Study on Hippophae rhamnoides flavonoids and their physiological functions. Beverage Ind. 2003, 6, 5-9. [CrossRef]

21. Xing, J.X. Comparative Study on Total Flavonoids Content in Different Parts of Hippophae Rhamnoides Linn. Shanxi Forestry Sci. Technol. 2018, 47, 4-5.

22. Fu, G.X.; Feng, R.Z.; Xiao, P.G. Determination and Comparison of Total Flavonoids in Seabuckthorn Leaves of Different Species and Different Harvesting Times. J. Tradit. Chin. Med. 1997, 22, 147-148. [CrossRef]

23. RiSch, D.; Krumbein, A.; Kroh, L.W. Antioxidant gallocatechins, dimeric and trimeric proanthocyanidins from sea buckthorn (Hippophae rhamnoides) pomace. Eur. Food Res. Technol. 2004, 219, 605-613. [CrossRef]

24. Panossian, A.; Wagner, H. From Traditional to Evidence-Based Use of Hippophae rhamnoides L.: Chemical Composition, Experimental, and Clinical Pharmacology of Sea Buckthorn Berries and Leaves Extracts. Evidence and Rational Based Research on Chinese Drugs; Wagner, H., Merzenich, G.U., Eds.; Springer-Verlag: Wien, Austria; London, UK; New York, NY, USA, 2013; Volume 5, pp. 181-236. [CrossRef]

25. Qin, Z.X.; Yu, Z.; Qi, M.D.; Zhang, Q.; Liu, S.; Li, M.H.; Liu, Y.G.; Liu, Y. Rapid analysis of compounds in leaves of Chinese seabuckthorn and Tibetan seabuckthorn by UPLC/Q-TOF-MS. Chin. J. Tradit. Chin. Med. 2016, 41, 1461-1468. [CrossRef]

26. Ran, B.B.; Li, W.D. Research progress on chemical constituents and their differences between seabuckthorn berries and leaves. Chin. J. Tradit. Chin. Med. 2019, 44, 1767-1773. 
27. Kumar, M.S.; Dutta, R.; Prasad, D.; Misra, K. Subcritical water extraction of antioxidant compounds from Seabuckthorn (Hippophae rhamnoides) leaves for the comparative evaluation of antioxidant activity. Food Chem. 2011, 127, 1309-1316. [CrossRef]

28. Zhang, S.M. Exttraction, Isolation and Identification of Flavones in Seabuckthorn (Hippophae rhamnoides L.) Fruits. Master's Thesis, Jilin Agricultural University, Jilin, China, 2004.

29. Chen, C.; Zhang, H.; Gu, H.; Yin, H.X.; Chen, Y. Flavonoid glycosides from Hippophae rhamnoides subsp. sinensis Rousi. West Chin. J. Pharmaceut. Sci. 2007, 22, 367-370.

30. Guliyev, V.B.; Gul, M.; Yildirim, A. Hippophae rhamnoides L.: Chromatographic methods to determine chemical composition, use in traditional medicine and pharmacological effects. J. Chromatogr. B 2004, 812, 291-307. [CrossRef]

31. Chen, C. Resources and Quality Evaluation of Genus Hippophae on Qinghai-Tibet Plateau. Ph.D. Thesis, Sichuan University, Chengdu, China, 2007.

32. Kim, J.S.; Kwon, Y.S.; Sa, Y.J.; Kim, M.J. Isolation and identification of sea buckthorn (Hippophae rhamnoides) phenolics with antioxidant activity and $\alpha$-glucosidase inhibitory effect. J. Agric. Food Chem. 2011, 59, 138-144. [CrossRef]

33. Chen, C.; Xu, X.M.; Chen, Y.; Yu, M.Y.; Wen, F.Y.; Zhang, H. Identification, quantification and antioxidant activity of acylated flavonol glycosides from sea buckthorn (Hippophae rhamnoides ssp. sinensis). Food Chem. 2013, 141, 1573-1579. [CrossRef]

34. Zhao, L.P.; Zhang, N.Z.; Xu, F.C. Study on Chemical Constituents of Hippophae thibetana. Anhui Agric. Sci. 2016, 44, 75-76. [CrossRef]

35. Liu, Y.; Lian, Y.S.; Wang, Y.L.; Li, M.H.; Xiao, P.G. Review of seabuckthorn research and development and its significance. Chin. J. Tradit. Chin. Med. 2014, 39, 1547-1552. [CrossRef]

36. Rosch, D.; Mugge, C.V.; Kroh, L.W. Antioxidant oligomeric proanthocyanidins from sea buckthorn (Hippophae rhamnoides) Pomace. J. Agric. Food Chem. 2004, 52, 6712-6718. [CrossRef] [PubMed]

37. Ruan, D.L.; Tao, H.R.; Li, H. Isolation and Identification of 4,4'-Diol-2'-methoxychalcone from Leaves of Seabuckthorn. Hippophae 2004, 17, 24-27.

38. Arimboor, R.; Kumar, K.S.; Arumughan, C. Simultaneous estimation of phenolic acids in sea buckthorn (Hippophae rhamnoides) using RP-HPLC with DAD. J. Pharmaceut. Biomed. Anal. 2008, 47, 31-38. [CrossRef]

39. Zhao, Y.Z.; Wu, F.H. Flavonoids in Hippophae rhamnoides and Their Medicinal Value. Hippophae 1997, $39-41$.

40. Shahidi, F.; Ambigaipalan, P. Phenolics and polyphenolics in foods, beverages and spices: Antioxidant activity and health effects-A review. J. Funct. Foods 2015, 18, 820-897. [CrossRef]

41. Sheichenko, O.P.; Sheichenko, V.I.; Fadeeva, I.I.; Zolotarev, B.M.; Tolkachev, O.N. Tannins from leaves of Hippophae rhamnoides. Chem. Nat. Comp. 1987, 23, 756-760. [CrossRef]

42. Yoshida, T.; Tanaka, K.; Chen, X.M.; Okuda, T. Tannins from Hippophae rhamnoides. Phytochemistry 1991, 30, 663-666. [CrossRef]

43. Zhang, J.W.; Wang, Y.; Xu, L.M.; Ma, X.L.; Sun, Y.X.; Jiang, W.P. Determination of gossypol in Hippophae rhamnoides L. seed oil. J. Nat. Sci. Jilin Univ. 1996, 3, 105-106.

44. McAuley, C.Y. Phenolic Compounds in Mentha spicata: Quantification, Identification and Antioxidant Activity. Master's Thesis, The University of Guelph, Guelph, ON, Canada, 2002.

45. Tan, P.X.; Ye, T.; Liu, X.X.; He, J.H. Research Advances in Antioxidant Composition of Botanical Extracts and Their Action Mechanisms. Food Sci. 2010, 31, 288-292.

46. Lu, X.X. Research Progress in Antioxidant Mechanism of Flavnonids. Food Res. Dev. 2012, 33, $220-224$. [CrossRef]

47. Wang, L.X.; Xie, Y.H.; Zhang, G.G. Application of Phytogenic Antioxidants and Its Mechanisms. J. Anim. Nut. 2017, 29, 1481-1488. [CrossRef]

48. Maheshwari, D.T.; Yogendra Kumar, M.S.; Verma, S.K.; Singh, V.K.; Singh, S.N. Antioxidant and hepatoprotective activities of phenolic rich fraction of Seabuckthorn (Hippophae rhamnoides L.) leaves. Food Chem. Toxicol. 2011, 49, 2422-2428. [CrossRef]

49. Wang, Y.; Huang, F.H.; Zhao, L.; Zhang, D.; Wang, O.; Guo, X.X.; Lu, F.; Yang, X.; Ji, B.P.; Deng, Q.C. Protective Effect of Total Flavones from Hippophae rhamnoides L. against Visible Light-Induced Retinal Degeneration in Pigmented Rabbits. J. Agric. Food Chem. 2016, 64, 161-170. [CrossRef] 
50. Zhang, J.C.; Wang, C.T.; Liu, Y.; Shi, X.Q.; Zhao, D.; Li, M.; Wang, C.T.; Sun, B.G. Anti-Aging Effect and Its Mechanism of Ethanol Extract from Sea Buckthorn Seed Meal in Caenorhabditis elegans. Food Sci. 2017, 38, 141-148. [CrossRef]

51. Reid, A.B.; Kurten, R.C.; McCullough, S.S.; Brock, R.W.; Hinson, J.A. Mechanisms of acetaminophen-induced hepatotoxicity: Role of oxidative stress and mitochondrial permeability transition in freshly isolated mouse hepatocytes. J. Pharmacol. Exp. Ther. 2005, 312, 509-516. [CrossRef] [PubMed]

52. He, S.; Rehman, H.; Wright, G.L.; Zhong, Z. Inhibition of inducible nitric oxide synthase prevents mitochondrial damage and improves survival of steatotic partial liver grafts. Transplantation 2010, 89, 291-298. [CrossRef] [PubMed]

53. Yang, Z.G.; Li, H.R.; Wang, L.Y.; Li, Y.H.; Lu, S.G.; Wen, X.F.; Wang, J.; Daikonya, A.; Kitanaka, S. Triterpenoids from Hippophae rhamnoides L. and their nitric oxide production-inhibitory and DPPH radical-scavenging activities. Chem. Pharm. Bull. 2007, 55, 15-18. [CrossRef]

54. Narayanan, S.; Ruma, D.; Gitika, B.; Sharma, S.K.; Pauline, T.; Sai Ram, M.; Ilavazhagan, G.; Swahney, R.C.; Kumar, D.; Banerjee, P.K. Antioxidant activities of seabuckthorn (Hippophae rhamnoides) during hypoxia induced oxidative stress in glial cells. Mol. Cellul. Biochem. 2005, 278, 9-14. [CrossRef]

55. Bai, H.M. Study of Seabuckthorn Flavonoids on Antioxidation and Immune Adjustment Function of Rats. Master's Thesis, Northeast Agricultural University, Harbin, China, 2009. [CrossRef]

56. Zhao, Y.; Zhang, L.; Li, H.; Cui, W.W.; Ren, Z.Y. The Research of Anti-oxidativ Function of Quercetin. Rain Fed. Crops. 2009, 29, 99-100. [CrossRef]

57. Li, X. Antiradical effects of tea polyphenols. Sci. Technol. Vision. 2014, 352-353. [CrossRef]

58. Zou, Y.; Lu, Y.; Wei, D. Antioxidant Activity of a Flavonoid-Rich Extract of Hypericum perforatum L. In Vitro. J. Agric. Food Chem. 2004, 52, 5032-5039. [CrossRef]

59. Upadhyay, N.K.; Kumar, M.S.Y.; Gupta, A. Antioxidant, cytoprotective and antibacterial effects of Sea buckthorn (Hippophae rhamnoides L.) leaves. Food Chem. Toxicol. 2010, 48, 3443-3448. [CrossRef] [PubMed]

60. Ting, H.C.; Hsu, Y.W.; Tsai, C.F.; Lu, F.J.; Chou, M.C.; Chen, W.K. The in vitro and in vivo antioxidant properties of seabuckthorn (Hippophae rhamnoides L.) seed oil. Food Chem. 2011, 125, 652-659. [CrossRef]

61. Amorati, R.; Valgimigli, L. Advantages and limitations of common testing methods for antioxidants. Free Radical Res. 2015, 49, 633-649. [CrossRef]

62. Benzie, I.F.F.; Strain, J.J. The Ferric Reducing Ability of Plasma (FRAP) as a Measure of "Antioxidant Power": The FRAP Assay. Anal. Biochem. 1996, 239, 70-76. [CrossRef]

63. Qi, L.N.; Jiang, J.L.; Zhang, J.F.; Zhang, L.L.; Wang, T. Curcumin Protects Human Trophoblast HTR8/SVneo Cells from H2O2-Induced Oxidative Stress by Activating Nrf2 Signaling Pathway. Antioxidants 2020, 9, 121. [CrossRef]

64. Wang, N.; Ma, H.P.; Qi, X.Z.; Meng, P.; Jia, Z.P. Progression of Nrf2-ARE Signaling Pathway in Protection of Oxidative Stress Injury of the Body. Med. Pharm. J. Chin. People's Liberation Army. 2015, 27, 21-27. [CrossRef]

65. Thimmulappa, R.K.; Mai, K.H.; Srisuma, S.; Kensler, T.W. Identification of Nrf2-regulated Genes Induced by the Chemopreventive Agent Sulforaphane by Oligonucleotide Microarray. Cancer Res. 2002, 62, 196-203. [CrossRef]

66. Kwak, M.K.; Akabayashi, N.; Itoh, K.; Motohash, H.; Yamamoto, M.; Kensler, T.W. Modulation of gene expression by cancer chemopreventive dithiolethiones through the Keap1-Nrf2 pathway: Identification of novel gene clusters for cell survival. Biol. Chem. 2003, 278, 8135-8145. [CrossRef]

67. Molagoda, I.M.N.; Lee, K.T.; Choi, Y.H.; Kim, G. Anthocyanins from Hibiscus syriacus L. Inhibit Oxidative Stress-mediated Apoptosis by Activating the Nrf2/HO-1 Signaling Pathway. Antioxidants 2020, 9, 42. [CrossRef] [PubMed]

68. Podder, B.; Kim, Y.S.; Song, H.Y. Cytoprotective effect of bioactive sea buckthorn extract on paraquat-exposed A549 cells via induction of Nrf2 and its downstream genes. Mol. Med. Rep. 2013, 8, 1852-1860. [CrossRef] [PubMed]

69. Zerin, T.; Kim, Y.S.; Hong, S.Y.; Song, H.Y. Protective effect of methylprednisolone on paraquat-induced A549 cell cytotoxicity via induction of efflux transporter, P glycoprotein expression. Toxicol. Lett. 2012, 208, 101-107. [CrossRef] [PubMed]

70. Na, H.K.; Surh, Y.J. Modulation of Nrf2-mediated antioxidant and detoxifying enzyme induction by the green tea polyphenol EGCG. Food Chem. Toxicol. 2008, 46, 1271-1278. [CrossRef] [PubMed] 
71. Kwak, M.K.; Itoh, K.; Yamamoto, M.; Kensler, T.W. Enhanced expression of the transcription factor Nrf2 by cancer chemopreventive agents: Role of antioxidant response element-like sequences in the nrf2 promoter. Mol. Cell. Biochem. 2002, 22, 2883-2892. [CrossRef]

72. Han, X.Q.; Zhang, C.X.; Zhang, W.J.; Xiang, B.Y.; Zhang, J.X. Effects of supplementation of different sea buckthorn pomace levels on antioxidation in testis and epi-didymis of ram. J. Shanxi Agric. Univ. (Nat. Sci. Edit.) 2017, 37, 733-742. [CrossRef]

73. Zhang, L.; Wan, N. Advances in the research of sport fatigue caused by the action of free radical lipid oxidation. Chin. J. Lab. Diagn. 2006, 1104-1108. [CrossRef]

74. Zhao, H.X.; Zhang, H.S.; Yang, S.F. Phenolic compounds and its antioxidant activities in ethanolic extracts from seven cultivars of Chinese jujube. Food Sci. Hum. Wellness 2014, 3, 183-190. [CrossRef]

75. Zadernowski, R.; Naczk, M.; Nowak-Polakowska, H.; Nesterowicz, J. Effect of sea buckthorn (Hippophae rhamnoides L.) berry extracts on the activity of lipase and lipoxygenase. J. Food Lipids 2012, 9, 249-258. [CrossRef]

76. Rop, O.; Ercisli, S.; Mlcek, J.; Jurikova, T.; Hoza, I. Antioxidant and radical scavenging activities in fruits of 6 sea buckthorn (Hippophae rhamnoides L.) cultivars. Turk. J. Agric. For. 2014, 38, 224-232. [CrossRef]

77. Wu, Y.; Wang, B.W.; Wang, Y.; Kang, J.; Wang, H.Y. Protective effect of the on myocardial ischemia and reperfusion injury in rats. Chin. Pharm. Bull. 1997, 1, 59-61.

78. Liu, Z.T.; Huang, J.; Wang, Y.X.; An, W.Q. Experiment effect of buckthron extract on lipofusion of cerebral tissues in wistar elderly rats. Chin. J. Gerontol. 2001, 21, 300-301.

79. Chen, R.; Wang, X.L.; Xu, H.H.; Sun, L.; Yu, Z.L. A Review on Antioxidant Activity of Antioxidants. J. Heze Univ. 2013, 35, 44-49. [CrossRef]

80. Li, F.H.; Guo, X.H.; Xia, C.Y.; Chen, L.; Ling, B.; Ming, J. Research Advance in Antioxidant Activity of Phenolic Compounds in Whole Grains. Food Sci. 2012, 33, 299-304.

81. Su, H.L.; Wei, J.; Bi, Y.; Li, J.X.; Yury, Z.; Alexander, K. Antioxidant activity of ethanol extracts from Chinese seabuckthorn berries in vitro and on HepG2 cells. Sci. Technol. Food Ind. 2017, 5, 51-55.

82. Varshneya, C.; Kant, V.; Mehta, M. Total phenolic contents and free radical scavenging activities of different extracts of seabuckthorn (Hippophae rhamnoides) pomace without seeds. Int. J. Food Sci. Nutr. 2012, 63, 153-159. [CrossRef]

83. Forman, H.J.; Davies, K.J.A.; Ursini, F. How do nutritional antioxidants really work: Nucleophilic tone and para-hormesis versus free radical scavenging in vivo. Free Radical Biol. Med. 2014, 66, 24-35. [CrossRef]

84. Haleagrahara, N.; Chakravarthi, S.; Kulur, A.B.; Tan, M.Y. Plant flavone apigenin protects against cyclosporine-induced histological and biochemical changes in the kidney in rats. Biomed. Prev. Nutr. 2014, 4, 589-593. [CrossRef]

85. Coskun, O.; Kanter, M.; Korkmaz, A.; Oter, S. Quercetin, a flavonoid antioxidant, prevents and protects streptozotocin-induced oxidative stress and $\beta$-cell damage in rat pancreas. Pharmacol. Res. 2005, 51, 117-123. [CrossRef]

86. Seo, K.; Yang, J.H.; Kim, S.C.; Ku, S.K.; Ki, S.H.; Shin, S.M. The Antioxidant Effects of Isorhamnetin Contribute to Inhibit COX-2 Expression in Response to Inflammation: A Potential Role of HO-1. Inflammation 2014, 37, 712-722. [CrossRef]

87. Mingjie, Z.; Huanhuan, R.; Jichun, H.; Wang, W.J.; Zheng, Q.S.; Wang, D. Protective Effects of Kaempferol against Myocardial Ischemia/Reperfusion Injury in Isolated Rat Heart via Antioxidant Activity and Inhibition of Glycogen Synthase Kinase-3ß. Oxid. Med. Cell Longev. 2015, 2015, 1-8. [CrossRef]

88. Barzegar, A. Antioxidant activity of polyphenolic myricetin in vitro cellfree and cell-based systems. Mol. Biol. Res. Commun. 2016, 5, 87-95. [PubMed]

89. Jayaraman, J.; Veerappan, M.; Namasivayam, N. Potential beneficial effect of naringenin on lipid peroxidation and antioxidant status in rats with ethanol-induced hepatotoxicity. J. Pharm. Pharmacol. 2010, 61, 1383-1390. [CrossRef]

90. Rajadurai, M.; Prince, P.S.M. Preventive effect of naringin on lipid peroxides and antioxidants in isoproterenol-induced cardiotoxicity in Wistar rats: Biochemical and histopathological evidences. Toxicology 2006, 228, 259-268. [CrossRef] [PubMed]

91. Piao, M.J.; Kang, K.A.; Zhang, R.; Ko, D.O.; Wang, Z.H.; You, H.J.; Kim, H.S.; Kim, J.S.; Kang, S.S.; Hyun, J.W. Hyperoside prevents oxidative damage induced by hydrogen peroxide in lung fibroblast cells via an antioxidant effect. BBA Gen. Subjects 2008, 1780, 0-1457. [CrossRef] 
92. Kalender, Y.; Kaya, S.; Durak, D.; Uzun, F.G.; Demir, F. Protective effects of catechin and quercetin on antioxidant status, lipid peroxidation and testis-histoarchitecture induced by chlorpyrifos in male rats. Environ. Toxicol. Pharmacol. 2012, 33, 0-148. [CrossRef]

93. Kamalakkannan, N.; Prince, P.S.M. Rutin improves the antioxidant status in streptozotocin-induced diabetic rat tissues. Mol. Cell Biochem. 2006, 293, 211-219. [CrossRef]

94. Punithavathi, V.R.; Prince, P.S.M.; Kumar, R.; Selvakumari, J. Antihyperglycaemic, antilipid peroxidative and antioxidant effects of gallic acid on streptozotocin induced diabetic Wistar rats. Eur. J. Pharmacol. 2011, 650, 465-471. [CrossRef]

95. Ramachandran, V.; Saravanan, R.; Raja, B. Attenuation of oxidative stress by syringic acid on acetaminophen-induced nephrotoxic rats. Comp. Clin. Pathol. 2012, 21, 1559-1564. [CrossRef]

96. Gülçin, I. Antioxidant activity of caffeic acid (3,4-dihydroxycinnamic acid). Toxicology 2006, 217, $213-220$. [CrossRef]

97. Zhou, Y.; Zhou, L.; Ruan, Z.; Mi, S.; Jiang, M.; Li, X.L.; Wu, X.; Deng, Z.Y.; Yin, Y.L. Chlorogenic acid ameliorates intestinal mitochondrial injury by increasing antioxidant effects and activity of respiratory complexes. Biosci. Biotechnol. Biochem. 2016, 1-10. [CrossRef] [PubMed]

98. Ghaisas, M.M.; Kshirsagar, S.B.; Sahane, R.S. Evaluation of wound healing activity of ferulic acid in diabetic rats. Int. Wound J. 2012, 11, 523-532. [CrossRef]

99. Qi, D.H.; Liu, H.C.; Liu, Q.J. Development of seabuckthorn healthy fruit nectar. Hippophae 2001, 14, $22-24$.

100. Guo, H.L. Letnod of Fermented Hippophae Composition for Improving Intestinal Immunity. Patent CN108208793A, 29 June 2018.

101. Li, Y. Liver-Protective Natural Product and Its Preparation Method. Patent CN103417752A, 5 August 2009.

102. Xiong, B.Q.; Yu, D.; Yuan, J.; Zeng, M.; Zhang, Y.; Du, J.B. The Wild Plant Resources and Utilization of Hippophae in China. Chin. Wild Plant Res. 2004, 23, 25-26.

103. Zou, W. Rich in Antioxidant Nutrient for Sea Buckthorn Fruit Peel Powder Complex Nutritional Meal Powder and Preparation Method Thereof. Patent CN108783292A, 13 November 2018.

104. Yan, J. A Kind of Sea-Buckthorn Health-Promoting Edible Salt and Preparation Method Thereof. Patent CN108283306A, 17 July 2018.

105. Smida, I.; Pentelescu, C.; Pentelescu, O.; Sweidan, A.; Oliviero, N.; Meuric, V.; Martin, B.; Colceriu, L.; BonnaureMallet, M.; Tamanai-Shacoori, Z. Benefits of sea buckthorn (Hippophae rhamnoides) pulp oil-based mouthwash on oral health. J. Appl. Microbiol. 2019, 126, 1594-1605. [CrossRef] [PubMed]

106. Wu, F.H.; Zhao, Y.Z. Folk prescription of Russian seabuckthorn skin care products. Hippophae 1997, 10, $39-41$.

107. Ren, M.; Gao, X.M. Limitation and Prospect of Animal experiment in the Research of traditional Chinese Medicine. Liaoning J. Tradit. Chin. Med. 2004, 31, 820-821. [CrossRef] 